\title{
Large-scale stable isotope alteration around the hydrothermal carbonate-replacement Cinco de Mayo Zn-Ag deposit, Mexico
}

\author{
Andreas Beinlich*: The Institute for Geoscience Research (TIGeR), School of Earth and \\ Planetary Sciences, Curtin University, Kent street, 6845 Perth, Australia \\ (andreas.beinlich@curtin.edu.au). Mineral Deposit Research Unit (MDRU), Department of \\ Earth, Ocean and Atmospheric Sciences, The University of British Columbia, 2207 Main \\ Mall, Vancouver, British Columbia V6T 1Z4, Canada.
}

Shaun L.L. Barker: Centre for Ore Deposit and Earth Sciences (CODES), University of Tasmania, Private Bag 79, Hobart, Tasmania 7001, Australia; Mineral Deposit Research Unit (MDRU), Department of Earth, Ocean and Atmospheric Sciences, The University of British Columbia, 2207 Main Mall, Vancouver, British Columbia V6T 1Z4, Canada.

Gregory M. Dipple: Mineral Deposit Research Unit (MDRU), Department of Earth, Ocean and Atmospheric Sciences, The University of British Columbia, 2207 Main Mall, Vancouver, British Columbia V6T 1Z4, Canada.

Lyle D. Hansen: MAG Silver Corp., Suite 770, 800 West Pender Street, Vancouver, British Columbia V6C 2V6 Canada.

Peter K.M. Megaw: MAG Silver Corp., Suite 770, 800 West Pender Street, Vancouver, British Columbia V6C 2V6 Canada.

$22 *$ Corresponding author.

24 Published as Large-Scale Stable Isotope Alteration Around the Hydrothermal Carbonate25 Replacement Cinco de Mayo Zn-Ag Deposit, Mexico

27 Economic Geology $114(2), 375-396$ 
ABSTRACT

31 Carbonate-hosted hydrothermal deposits typically show narrow visible mineralogical and 32 textural alteration halos, which inhibits exploration targeting. In contrast, hydrothermal 33 modification of the country rock's stable isotope composition usually extends far beyond the 34 limited visible alteration. Hence, stable isotope studies should be an effective tool to aid 35 exploration for carbonate-hosted deposits. Here we present new insight into the development of 36 a large stable isotope alteration halo based on $910 \mathrm{O}$ and $\mathrm{C}$ isotope analyses of carbonate veins and hydrothermally altered limestone hosting the Cinco de Mayo $\mathrm{Pb}-\mathrm{Zn}-\mathrm{Ag}(\mathrm{Au}, \mathrm{Cu})$ Carbonate 38 Replacement Deposit (CRD), in Chihuahua, Mexico. Our results demonstrate that stable isotope alteration is consistent with reactive, magmatic fluid flow into unaltered limestone and represents a powerful tool for the characterization of these hydrothermal ore systems. Syn-mineralization veins are texturally and isotopically distinct from those formed during pre- and postmineralization diagenesis and fluid flow and show distinct gradients along the direction of mineralizing fluid flow: this appears to be a promising exploration vectoring tool. Downhole variations in wall rock isotope values reveal aquifers and aquicludes and outline the principal hydrothermal flow paths. Furthermore, wall rock $\delta^{18} \mathrm{O}_{\text {vSMOw }}$ systematically decreases towards mineralization from $\sim 23 \%$ o to $<17 \%$ over a distance of $\sim 10 \mathrm{~km}$, providing another vectoring tool.

47 The extent of the stable isotope alteration halo likely reflects the overall fluid volume and areal 48 extent of a fossil hydrothermal system, which may be expected to scale with the mineral 49 endowment. This suggests that constraining the size, shape and degree of isotopic alteration has 50 direct application to mineral exploration by outlining the system and indicating the potential size 51 of a deposit. 
The stable isotope compositions of natural fluids and rocks are generally different, so mineral replacement reactions occurring during hydrothermal rock alteration often result in distinctly modified isotope ratios $\left(\delta^{18} \mathrm{O}, \delta^{13} \mathrm{C}\right)$ of the affected rock relative to its precursor (Cathles, 1993; Taylor, 1974, 1979; Taylor and Epstein, 1963). Hydrothermal ore deposit formation involves large volumes of disequilibrium fluids that interact with the country rock causing halos of isotopic alteration (e.g. $\delta^{18} \mathrm{O}$ and $\delta^{13} \mathrm{C}$ ) showing values distinct from more distal, unaltered rocks. These disequilibrium fluids also commonly deposit secondary carbonate veins with distinct isotopic values. The spatial extent of isotopic alteration and isotopically distinctive carbonate veins usually extends far beyond zones of visible alteration and metal enrichment (e.g. Criss et al., 1985). Therefore, stable isotope mapping represents a potentially powerful prospecting tool complementing other mineral exploration techniques (e.g., mineralogy, lithogeochemistry, geophysics).

The extent and degree of isotopic alteration of a given host rock depends on the fluid transport mode (pervasive or channelized), fluid and rock composition, fluid volume and temperature dependent reaction kinetics (e.g., Frimmel, 1992; Lassey and Blattner, 1988). The utilization of stable isotope studies in exploration for hydrothermal ore deposits in carbonate rocks is particularly attractive because they typically develop very limited visible alteration zones immediately around fluid flow paths (see also Criss et al., 2000; Ewers et al., 1994; Kelley et al., 2006; Large et al., 2001; Taylor, 1997; Vazquez et al., 1998; Waring et al., 1998). Even though stable isotope studies can yield critical constraints on fluid composition and source, alteration temperature and size of the hydrothermal system, their practical application is surprisingly limited to only one successful documented discovery (Naito et al., 1995). Historically, the main reasons for the limited practical deployment of stable isotope mapping in mineral exploration were unacceptably high costs of data collection and long turn-around times. Consequently, stable isotope studies of hydrothermally altered country rocks have been limited to purely academic research despite the potential for improving mineral exploration in some environments (Barker et al., 2013; Dilles et al., 1992; Hickey et al., 2014; Jamtveit et al., 1992; Millonig et al., 2017; Murakami and Nakano, 1999).

This study aims to further understanding of how the stable isotope compositions of hydrothermally altered limestone can be used as a vectoring tool in carbonate replacement deposits through use of an off-axis integrated cavity output spectrometer that allows for high sample throughput at minimal analytical cost (OA-ICOS) (Barker et al., 2011; Barker et al., 2013; Beinlich et al., 2017). Vein and wall rock carbonate samples $(n=910)$ from 16 drill holes around the Cinco de Mayo Pegaso Zone mineralization were examined and analyzed for textural characteristics and isotope and trace-element compositions to define the overall extent of the stable isotope alteration footprint, identify fluid and metal transport pathways, and to assess the 
hosted manto systems. The results provide new constraints on the volume of alteration fluids, their composition and source, and the critical dimensions of fluid transport in a large hydrothermal system.

\section{GEOLOGICAL CONTEXT}

\section{General overview}

The Cinco de Mayo $\mathrm{Zn}-\mathrm{Ag}$ carbonate replacement deposit (CRD) is located in the State of Chihuahua, Mexico approximately $\sim 190 \mathrm{~km}$ north of the capital, Chihuahua City (Robertson and Megaw, 2009). Cinco de Mayo is one of a family of CRDs that define a belt $2200 \mathrm{~km}$ long along the interface between the Tertiary Volcanic Plateau of the Sierra Nevada Occidental and the Laramide Mexican Thrust Belt (Megaw et al., 1988). The most significant CRDs are hosted in carbonate successions of the Chihuahua and Sierra Madre terranes, which together with the Coahuila and Maya terranes are underlain by Paleozoic or possibly older continental crust (Ruiz et al., 1988). Mineralization throughout the belt occurs in a limestone-dominant transgressive sedimentary succession deposited during Jurassic-Cretaceous flooding of pre-Middle-Triassic basement terranes (Haenggi, 2002). This basement was block-faulted during middle-Jurassic extension, creating a series of linear basins, including the Chihuahua Trough that controlled sedimentation (Megaw et al., 1996). The deposit is situated at the western boundary of the Chihuahua Trough where thrust sheets of Cretaceous limestone, shale, and sandstone were stacked by basin inversion during NE-SW directed Laramide compression between $\sim 84 \mathrm{Ma}$ and $\sim 43 \mathrm{Ma}$ (Muehlberger, 1993). This NE-SW compression was accompanied by gentle to tight folding and extensive axial faulting and fracturing (Handschy and Dyer, 1987; Hewitt, 1966) that created structurally enhanced permeability subsequently exploited by mid-Tertiary intrusions ranging in composition from diorite through rhyolite. Hydrothermal fluids related to these magmas also followed these deformation zones; depositing a range of skarn, CRD and vein deposits (Clark and de la Fuente L, 1978; Megaw et al., 1988). Megaw et al. (1988) noted that mineralization is commonly hosted in limestone layers capped by impermeable strata that confined fluid flow and mineral precipitation to distinct zones. Lead isotope data from mineral deposits in northern Mexico suggest substantial reworking of $\mathrm{Pb}$ from underlying Precambrian crust during Cenozoic volcanism linked to rapid spreading at the East Pacific Rise prior to the opening of the Gulf of California (Cumming et al., 1979; McDowell and Keizer, 1977; NietoSamaniego et al., 1999). The timing of mineralization throughout the region is bracketed between 57.9 Ma and 25.9 Ma, coinciding with the main period of the Tertiary Sierra Madre Occidental volcanic activity, with maxima between $35 \mathrm{Ma}$ and $29 \mathrm{Ma}$ (Camprubi et al., 2006; Megaw et al., 1988; Velador et al., 2010).

\section{The Cinco de Mayo Carbonate Replacement Deposit}

Cinco de Mayo is a recently discovered $\mathrm{Ag}-\mathrm{Pb}-\mathrm{Zn}$ carbonate replacement deposit within a 25,000 hectare concession $100 \%$ owned by MAG Silver Corp. The property is centered on the 
Sierra Santa Lucia, a $4 \mathrm{~km}$ wide, $15 \mathrm{~km}$ long ridge composed of imbricated thrust sheets of limestone, sandstone and shale. The sierra is surrounded by a flat, featureless alluvial plain that stretches for several kilometers in all directions. This plain is interrupted on its east side by a $0.5 \times 2.0 \mathrm{~km}$ long elongated limestone ridge (Cerro Cinco de Mayo) cut by numerous mineralized jasperoid veins (Robertson and Megaw, 2009). Exploration began in 2006 along this ridge and rapidly progressed into the surrounding covered areas guided by repeated iterations of geological interpretation, airborne geophysical surveys and drilling. This ultimately defined mineralization in imbricated slices of limestone along the NW-trending Jose Thrust Fault. Concurrent exploration through the alluvial cover about $4 \mathrm{~km}$ to the SW along the west side of the Sierra Santa Lucia discovered the Pozo Seco Zone mineralization in 2008. The Pozo Seco Zone also lies directly along a major thrust fault and consists of a tabular jasperoid body, $\sim 2.5 \mathrm{~km}$ long, 250 to $300 \mathrm{~m}$ wide, and 17 to $250 \mathrm{~m}$ thick, carrying average grades of $0.15 \% \mathrm{Mo}$ and $0.25 \mathrm{ppm} \mathrm{Au}$ (MacInnis, 2009, 2010).

Initial drilling at Cinco de Mayo Ridge in 2007 intersected minor massive sulfides plus massive hornfels alteration cut by dispersed and veinlet $\mathrm{Zn}-\mathrm{Pb}$ sulfide mineralization (Robertson and Megaw, 2009). Continued drilling between 2007 and 2012 discovered and defined the "Upper Manto", a continuous body of massive sulfides averaging $5 \mathrm{~m}$ thick, $450 \mathrm{~m}$ down dip and 4,000 m long. In mid-2012 drill hole CM12-431, directed beneath the centre of the Upper Manto, encountered the Pegaso Zone comprised of three major massive sulfide zones $(3.12 \mathrm{~m}$, $20.15 \mathrm{~m}$ and $61.6 \mathrm{~m}$ in core length) lying within a zone of pervasive skarn and marble approximately $400 \mathrm{~m}$ thick. The thickest intercept $(61.1 \mathrm{~m})$ graded $89 \mathrm{~g} / \mathrm{t}$ silver, $0.78 \mathrm{~g} / \mathrm{t}$ gold, $0.13 \%$ copper, $2.1 \%$ lead and $7.3 \%$ zinc (MacInnis, 2012). Despite the pervasive skarn and marble development, no intrusions were cut in the hole. The entire progression of continuous mineralization from the Upper Manto to the Pegaso Zone is completely blind, with no outcrop expression whatsoever.

The known mineralization is hosted within fossiliferous limestone of the Lower Cretaceous Finlay Formation along NE-SW and NW-SE trending structures, dominantly where faulted against impermeable shales and sandstones of the Upper Cretaceous Benavides Formation (Lyons, 2008). Mineralization occurs as relatively flat lying to inclined sheet-like massive sulfide "manto" (Spanish for "cloak" or "blanket") replacement bodies in the limestone with sulfide mineralized veinlets in the hanging wall shales and sandstones. Mantos consist of massive fine to coarse-grained pyrite, pyrrhotite, galena, sphalerite, with minor chalcopyrite and acanthite. Domains of unreplaced limestone are common within the massive sulfides. Common gangue minerals include barite, fluorite, and manganoan calcite (Megaw et al., 2014). Coarsegrained sulfide--mineralized veinlets dominated by Mn-calcite occur along vein walls, in calcitecemented breccia, and as stringers replacing the vein calcite. Sulfide minerals are commonly banded, mimicking sedimentary features of the precursor limestone but frequently show postdepositional brecciation and recrystallization. Mineralization becomes progressively surrounded 
by recrystallized limestone to coarse grained marble and garnet skarn approaching the Pegaso Zone.

\section{Local stratigraphy}

Mineralization at Cinco de Mayo is related to the interplay between ore-fluids related to Cenozoic silicic magmatism and Jurassic-Cretaceous limestones, clastic sediments and evaporates deposited in the Jurassic Chihuahua Trough deformed by Laramide compression. The evaporite sequences are dominated by gypsum and/or anhydrite with interbedded shale, whereas the clastic sediments are composed of conglomerate sandstone, siltstone and shale (Selway and Leonard, 2008). Cinco de Mayo mineralization is hosted by thrusted Cretaceous fossiliferous limestone units of Early to Middle Albian age (Table 1). Although the deformation renders precise correlation with the regional stratigraphy somewhat challenging, exposed limestones are interpreted to include the Late Aptian Cuchillo Formation at the base, overlain by the Benigno, Lagrima, and Finlay Formations. The Late Albian Benavides Shale caps the sequence. The Finlay Formation is the most important host for mineralization. It is a relatively clean limestone with local cherty beds, high energy beach zones and reefs (Lyons, 2008). The overlying Benavides Shale consists mostly of shale and may have played an important role as an aquitard capping hydrothermal fluid movements during mineralization. The upper Albian and Cenomanian Loma de Plata, Ojinaga and Indidura Formations of the regional stratigraphy are not reported in outcrop at Cinco de Mayo (Lyons, 2008).

\section{METHODS}

Samples

Wall rock carbonate and vein calcite samples were taken from half-core from 16 drill holes located through the NW-SE trending Pegaso Zone and along a $\sim 12 \mathrm{~km} \mathrm{NNW-SSE} \mathrm{trending}$ transect from the Pegaso Zone to the most distal drill hole in the far SE corner of the Cinco de Mayo property. Six additional drill holes from the vicinity of the two transects were also sampled (Fig. 1). Based on the location relative to the Upper Manto/Pegaso Zone mineralization, these drill holes are labelled 'mineralization zone', 'proximal', and 'distal', respectively. Mineralization zone samples are dominantly from the Pegaso Zone (CM07-20, CM12-423, CM12-431, CM12-428, and CM11-380) together with additional samples from the Pozo Seco Zone (CM10-247). Proximal samples are dominantly from drill holes located to the S and SE of the Pegaso Zone (CM06-01, CM10-317, CM10-305, CM10-127, and CM10-292) and define a transect bridging the area between the mineralization and the distal drill holes (CM09-88, CM09-89, and CM09-94) in the SE corner of the property. This transect is parallel to the general strike of thrusting in the area and was chosen to discern the extent of fluid flow and stable isotope alteration in the subsurface. CM08-45 is located to the NW of the Pegaso Zone and was regarded as the 'most barren looking hole' on the Cinco de Mayo property during exploration drilling (Megaw, pers. comm.) and was initially expected to reflect the local stable isotope 
background. However, its stable isotope values fall in the "proximal" range. Thus, CM09-94, which shows the least isotopically altered values, was taken as the stable isotope background against which the composition of all other samples are compared.

Stable isotope analyses were conducted on carbonate powder drilled from selected sites on solid half-core samples using a handheld Dremel ${ }^{\mathrm{TM}}$ tool. The drill bit was cleaned in $10 \% \mathrm{HCl}$ and ethanol after each sample to avoid cross-contamination between samples. Sites for microsampling were chosen based on macroscopic investigation of half-core samples under normal and UV light and assay data provided by MAG Silver. Micro sampling sites include different vein generations and their respective wall rocks.

\section{Macroscopic investigation}

For initial investigation half-core samples were chosen based on downhole location to allow for even spacing, with increased density near mineralization. Subsequent sampling focused on vein-wall rock pairs from the Finlay Formation. Samples were photographed under normal and UV light to identify micro sampling sites and distinct vein generations based on UV fluorescence color and intensity, cross-cutting relationships, deformation features, and the macroscopic appearance of the vein-wall rock interface.

\section{Stable isotope analysis}

Approximately $35 \mathrm{mg}$ of carbonate powder was placed into unflushed $12 \mathrm{~mL}$ Labco borosilicate glass vials that were sealed with butyl rubber septa. About 15 drops of $85 \% \mathrm{H}_{3} \mathrm{PO}_{4}$ was injected into each vial through the rubber septum and left to react with the carbonate powder for $\sim 1$ hour on an aluminium block heated to $72^{\circ} \mathrm{C}$. Following digestion, sample gas released from the dissolved carbonate was introduced into an off-axis integrated cavity output spectrometer (OA-ICOS; Los Gatos Research (LGR) model 908-0021 and CCIA-46) via a stainless steel tubing line with a cold trap to freeze out water vapor (Barker et al., 2011). The OA-ICOS instrument simultaneously measures the volume fraction of $\mathrm{CO}_{2}$ isotopologues $\left({ }^{12} \mathrm{C}^{16} \mathrm{O}^{16} \mathrm{O},{ }^{13} \mathrm{C}^{16} \mathrm{O}^{16} \mathrm{O},{ }^{12} \mathrm{C}^{16} \mathrm{O}^{18} \mathrm{O}\right)$ by high-resolution laser absorption in the near-infrared range. A more detailed summary of the OA-ICOS theory and its application to carbonate minerals can be found in Baer et al. (2002) and Barker et al. (2011). LGR model 908-0021 is incapable of accurately measuring the isotope composition of $\mathrm{CO}_{2}-\mathrm{H}_{2} \mathrm{~S}$ mixtures, which results from acid digestion of sulfide-bearing carbonate samples. These samples were analyzed using a second generation ICOS instrument (LGR CCIA-46), equipped with a modified laser system that avoids laser absorption by $\mathrm{H}_{2} \mathrm{~S}$ (Beinlich et al., 2017). The stable isotope composition is reported as $\delta$-values in per mil (\%), i.e. as parts per thousand difference from a standard (Faure and Mensing, 2005):

$$
\delta \mathrm{X}=\left[\left(\mathrm{R}_{\text {sample }} / \mathrm{R}_{\text {standard }}\right)-1\right] \times 10^{3},
$$


where $\mathrm{X}$ denotes ${ }^{13} \mathrm{C}$ or ${ }^{18} \mathrm{O}$ and $\mathrm{R}$ is ${ }^{13} \mathrm{C} /{ }^{12} \mathrm{C}$ and ${ }^{18} \mathrm{O} /{ }^{16} \mathrm{O}$, respectively. Throughout the text we describe relatively high $\delta$-values as 'heavy' or 'enriched' and relatively low $\delta$-values as 'light' or 'depleted'. Repeated analyses of the UBC-MDRU calcite in-house standard BN13 indicate that the measurements are accurate with a standard error of $0.6 \%$ ( $1 \mathrm{SE})$ for $\delta^{18} \mathrm{O}$ and $0.5 \%$ (1 SE) for $\delta^{13} \mathrm{C}$ (Barker et al., 2011). All isotope values in this report are standardized to Vienna Standard Mean Ocean Water (VSMOW) and Vienna Pee Dee Belemnite (VPDB) for oxygen and carbon, respectively. The standard deviation given in the text refers to the $68 \%$ confidence interval $(1 \sigma)$. A total of $910 \mathrm{O}$ and $\mathrm{C}$ isotope analyses were conducted for this study.

\section{Trace-element analysis}

Laser ablation ICP-MS measurements of a series of trace-elements was carried out using a ASI Resolution S155-SE laser ablation system, based on a $193 \mathrm{~nm}$ ArF excimer laser (ATL) attached to a $\mathrm{N}_{2}$ purged-beam delivery unit at the University of Waikato, New Zealand. A spot size of $100 \mu \mathrm{m}$ and laser fluence of $\sim 6 \mathrm{~J} \mathrm{~cm}^{-2}$ was used. Ablation took place in a two-volume cell, developed by Laurin Technic (Müller et al., 2009). Before analysis, the cell was vacuum purged and then filled with $\mathrm{He}$, which washed the ablated aerosol out of the cell. The carrier gas was mixed with Ar in the cone that sits above the zone where ablation takes place, and was then mixed downstream with a small amount of $\mathrm{N}_{2}(6 \mathrm{~mL}$ per minute) to increase plasma temperature (Hu et al., 2008). The ablation aerosol was transported through a nylon manifold signal smoothing device ("squid") before reaching the torch of a Perking Elmer Elan II ICP-MS. The ICP-MS was tuned using NIST 612 glass for high sensitivity and low oxide production rates (ThO/Th $<0.5 \%$ ). The quadrupole mass analyzer sequentially peak shifts between masses of interest (Mg, Si, P, S, Mn, Fe, Cu, Zn, As, Sr, Y, Ba, La, Ce, Pr, Nd, Sm, Eu, Gd, Tb, Dy, Ho, Er, $\mathrm{Tm}, \mathrm{Yb}, \mathrm{Hf}, \mathrm{Tl}, \mathrm{Pb}, \mathrm{Th}, \mathrm{U}$ ) during the laser ablation process, with a sweep time over the entire mass range of less than 1 second. 40 seconds of laser ablation data was collected for each analysis point, and at least 20 seconds of gas blank were collected for each sample. The ICP-MS collected data continuously in time-resolved analysis mode, with gas blanks collected before and after each laser ablation point to facilitate blank subtraction. NIST 612 was used as a calibration standard. Data reduction followed established protocols for time-resolved analysis (Longerich et al., 1996). Iolite software (Hellstrom et al., 2008) was used for data reduction, with ${ }^{43} \mathrm{Ca}$ used as an internal standard. Carbonate minerals were assumed to be pure calcite, with $\mathrm{Ca}=40.04 \mathrm{wt} \%$ for the internal standard. As laser ablation ICP-MS results are reported relative to the external standard value, a $\pm 5 \%$ variation in this value will lead to an uncertainty of $\sim 13 \%$ in the calculated trace-element concentrations.

\section{RESULTS}

Stable isotope analysis was initially focused on identifying the preferential fluid flow path at Cinco de Mayo by sampling at high spatial resolution at intervals between $2 \mathrm{~m}$ and $7 \mathrm{~m}$ and across formation boundaries. Based on the variability and absolute values of stable isotope ratios, 
we identified the Finlay Formation as the principal aquifer, which then became the main focus of subsequent sampling. The downhole distribution of $\mathrm{O}$ and $\mathrm{C}$ isotope ratios in vein and wall rock samples of the most mineralized drill hole (CM12-431) was compared with that of the least altered drill hole (CM09-94) in Figure 2, showing the distribution of stable isotope ratios across several limestone formations. The stable isotope ratios of the non-aquifer formations (Table 2) are generally higher and show less dispersion with depth than those of the Finlay Formation. The spreads in $\mathrm{O}$ and $\mathrm{C}$ isotope ratios of all Finlay wall rock and vein samples are shown as box plots in Figure 3 in the general order of increasing distance from CM12-431. CM12-431 has been chosen as the point of "origin" due to the presence of strong mineralization surrounded by hundreds of metres of pervasive marble, hornfels and skarn alteration indicating proximity to the likely heat and fluid source. CM10-247 is situated in a different mineralization zone $4 \mathrm{~km}$ to the W (Pozo Seco Zone) but is considerably altered and is therefore placed to the left of CM12-431 in Figure 3.

\section{Local stable isotope background - distal hole CM09-94}

The local stable isotope background is defined as the composition of distal hole CM09-94 in the SE part of the Cinco the Mayo property. The distance of CM09-94 to the Pegaso Zone is $\sim 12.7 \mathrm{~km}$. CM09-94 intersects the Benavides, Finlay and Lagrima Formations, all of which have constant $\delta^{13} \mathrm{C}$ and $\delta^{18} \mathrm{O}$ values throughout the entire length of the core (Fig. 2A). Averaged wall rock $\delta^{13} \mathrm{C}$ and $\delta^{18} \mathrm{O}$ values are $3.1 \pm 0.7 \%$ and $22.4 \pm 1.7 \%$, respectively $(\mathrm{n}=72)$. The composition of the Finlay limestone in CM09-94 is shown in Figure 3A (Table 3).

\section{Proximal and distal drill holes}

The distal and proximal drill holes show average $\delta^{13} \mathrm{C}$ and $\delta^{18} \mathrm{O}$ values slightly below the local stable isotope background defined by CM09-94. The variations of isotope ratios with depth in these holes are more pronounced than in CM09-94. CM10-305 and CM10-292 are mostly within the Finlay Formation, CM09-127 intersects the Benavides, Finlay, Lagrima, and Benigno Formations and CM09-88 cut just the Benigno and Cuchillo Formations. CM08-45 and CM10332 are located $\sim 3 \mathrm{~km}$ to the NW and W from the Pegaso Zone, respectively. Samples from these two drill holes are from the Finlay Formation and are significantly depleted in ${ }^{18} \mathrm{O}$ and slightly depleted in ${ }^{13} \mathrm{C}$ relative to the local background. CM06-01 is located directly to the SW of the Pegaso Zone. The average Finlay wall rock $\delta^{13} \mathrm{C}$ values for proximal samples vary between $0.9 \pm 1.2 \%$ and $2.7 \pm 0.8 \%$ o, $\delta^{18} \mathrm{O}$ values vary between $15.5 \pm 2.9 \%$ and $20.8 \pm 1.3 \%$ (Fig. $3 \mathrm{~A}$; Table 3).

\section{Mineralization zone samples}

Most of the investigated mineralization zone samples intersect the Pegaso Zone with one additional sample from the Pozo Seco Zone. Mineralization zone samples are characterized by highly variable isotope ratios with variations of up to $10 \%$ for both oxygen and carbon over 
depth intervals of $10 \mathrm{~m}$ or less (Fig. 2B). Average stable isotope ratios (shown as the five point moving average in Fig. 2) are significantly shifted to lower values compared to the local stable isotope background and proximal samples. CM12-431 intersects three mineralized zones where carbonate has been completely replaced by massive sulfide on the meter to tens of meters scale. The contact between massive sulfide and limestone host rock in CM12-431 is often characterized by meter wide zones of white recrystallized calcite. Samples from these contact zones display the most depleted values, to as low as $\delta^{13} \mathrm{C}=-6 \%$ and $\delta^{18} \mathrm{O}=10 \%$.

The depth interval with the strongest variation and lowest average stable isotope ratios coincides with intervals having high metal (e.g. Ag in Fig. 2B) and S concentrations within CM12-431 and CM12-423. Even though stable isotope alteration is preferentially developed in the Finlay Formation, it extends into the underlying Lagrima shale and Benigno limestone (Fig. 2B). Samples from the stratigraphically higher Benavides shale are often characterized by low carbonate mineral abundance and only a small number of samples could be analyzed owing to the lack of carbonate minerals. Average stable isotope ratios of Finlay limestone in CM12-431 and $\mathrm{CM} 12-423$ are $\delta^{13} \mathrm{C}=1.8 \pm 1.2 \%(\mathrm{n}=43), 1.9 \pm 1.2 \%$ ( $(\mathrm{n}=90)$ and $\delta^{18} \mathrm{O}=17.2 \pm 2.7 \%$ and 19.6 $\pm 2.2 \%$, respectively (Fig. 3A; Table 3 ). The isotope ratios gradually increase with depth and approach values identical to the local stable isotope background. This transition zone has a thickness of $\sim 200 \mathrm{~m}$ in both drill holes (Fig. 2B; only shown for CM12-431). CM10-247 from the Pozo Seco Zone intersects the Finlay, Lagrima, Benigno, and Cuchillo Formations. The isotope ratios are consistently offset to lower values throughout the entire core and do not increase at depth (Tables 2 and 3). The average Finlay wall rock $\delta^{13} \mathrm{C}$ is $2.5 \pm 0.7 \%$ and $\delta^{18} \mathrm{O}$ is $14.5 \pm 1.3 \%$ (Figs. 2 and 3 ).

\section{Vein generations}

Three generations of carbonate veins could be distinguished at Cinco de Mayo based on macroscopic textural observations and UV fluorescence. Throughout the following text, the different vein generations are referred to as G1, G2 and G3 veins with G1 being the first (oldest) and G3 the last (youngest) generation.

Generation 1 veins. The first vein generation displays a white color under normal light and shows evidence of ductile deformation, i.e. is often boudinaged and/or folded on hand specimen scale. Interfaces between G1 veins and their wall rocks are typically diffuse. G1 veins are crosscut by later, texturally distinct, vein generations G2 and G3 (Fig. 4A-C). Based on hand specimen observations, G1 veins are pure calcite and sulfide minerals have not been found in this vein type. The majority of veins showing these textural features are generally UV inactive but a very weak pink fluorescence was locally observed (Fig. 4A).

Generation 2 veins. On hand specimen scale, G2 veins are either straight or show evidence of brittle deformation. Interfaces with the surrounding wall rock are always sharp. G2 veins usually show a strong pink, or sometimes a blue UV fluorescence color and are rarely UV 
inactive (Fig. 4B-F). Where cross-cutting relationships are evident, G2 veins are consistently younger than G1 veins. Heavily veined samples sometimes exhibit mutual cross-cutting relationships of veins consistent with the textural characteristics of G2 veins (Fig. 4F). These cross-cutting G2 veins have been arbitrarily classified as vein types $G 2 a$ and $G 2 b$ with $G 2 b$ veins being younger. G2 veins frequently contain uncharacterized sulfide minerals and ankerite in addition to calcite.

Generation 3 veins. This third vein generation is distinguished based on textural relationships with sulfide minerals. While G2 veins are frequently sulfide bearing, G3 veins cross-cut sulfide minerals and zones of massive sulfide mineralization. Such G3 veins are undeformed and sometimes show a weak pink UV fluorescence color (Fig. 4G and F). Interfaces with the surrounding sulfide host mineral are sharp and ankerite has not been detected in G3 veins. However, the absence of cross-cutting relationships means textural classification criteria alone are insufficient to distinguish G2 and G3 veins outside of mineralized zones.

\section{Vein carbonate stable isotope ratios}

The stable isotope ratios of all analyzed calcite veins and their classification into the three vein generations is shown in Figure 5. The downhole distribution of vein calcite stable isotope ratios is shown for cores CM12-431 and CM09-94 in Figure 2. G1 veins show a wide spread of positively correlated $\delta^{13} \mathrm{C}$ and $\delta^{18} \mathrm{O}$ values ranging from $-4 \%$ to $3 \%$ and $15 \%$ to $22 \%$, respectively (Fig. 5). G2 veins show a similar spread in $\delta^{13} \mathrm{C}$ values between -3\%o and 4\%, while $\delta^{18} \mathrm{O}$ values vary between $10 \%$ and $18 \%$. The compositional ranges of the two vein generations overlap but cluster in distinct areas on a $\delta^{18} \mathrm{O}$ vs. $\delta^{13} \mathrm{C}$ plot (Fig. 5). The stable isotope composition of $\mathrm{G} 2 \mathrm{~b}$ veins overlaps with that of $\mathrm{G} 2 \mathrm{a}$ veins and ranges in $\delta^{13} \mathrm{C}$ between $1.5 \%$ and $2.5 \%$ and in $\delta^{18} \mathrm{O}$ between $14 \%$ and $19 \%$ (Fig. 5). G3 veins have a distinct stable isotope composition that is strongly depleted in both ${ }^{13} \mathrm{C}$ and ${ }^{18} \mathrm{O}$ relative to $\mathrm{G} 1$ and $\mathrm{G} 2$ veins. $\delta^{13} \mathrm{C}$ values vary between $-3 \%$ and $-1 \%, \delta^{18} \mathrm{O}$ between $8 \%$ and $13 \% 0$ (Fig. 5). The isotopically distinct composition of $\mathrm{G} 3$ and $\mathrm{G} 2 \mathrm{~b}$ veins supports their classification as separate generations. The compositional overlap of G3 veins with depleted G2a veins complicates their classification and a definitive classification is not always possible. Isotope ratios of G2 veins hosted in Finlay limestone are shown as box plots in Figure 3B.

\section{Vein carbonate trace-element concentrations}

Vein carbonate trace-element concentrations were measured on representative samples of the three vein generations and from mineralization zone, proximal and distal cores. Concentrations were measured for $\mathrm{Mg}, \mathrm{Si}, \mathrm{P}, \mathrm{S}, \mathrm{Mn}, \mathrm{Fe}, \mathrm{Cu}, \mathrm{Zn}, \mathrm{As}, \mathrm{Sr}, \mathrm{Y}, \mathrm{Ba}, \mathrm{Hf}, \mathrm{Tl}, \mathrm{Pb}, \mathrm{Th}, \mathrm{U}$ and rare earth elements (REE). Generally, trace-element concentrations are low except those of $\mathrm{Si}, \mathrm{Mg}$, Fe and Mn (435 - $4050 \mathrm{ppm})$. Sulfur and $\mathrm{Sr}$ concentrations range between $30 \mathrm{ppm}$ and $10 \mathrm{ppm}$, concentrations of all other analyzed elements are below $10 \mathrm{ppm}$ and mostly also below 1 ppm. In most samples $\mathrm{P}, \mathrm{Hf}, \mathrm{Tl}$, and $\mathrm{Th}$ are below detection limits. Likewise, the heavy REE 
(HREE) $\mathrm{Tm}$ and $\mathrm{Yb}$ are generally near or below their detection limits $(\sim 0.03 \mathrm{ppb})$. Average trace-element concentrations on a per-vein basis are summarized in Table 4.

Systematic trace-element concentration differences exist between the different vein generations. The average concentrations of all analyzed trace-elements are enriched in G2 and G3 veins relative to G1 veins except Sr, which has similar concentrations in all three vein generations. The strongest enrichment ( $>10$ times enriched) in average concentrations in G2 relative to $\mathrm{G} 1$ veins is found for $\mathrm{Mn}, \mathrm{Fe}, \mathrm{Y}$ and REE. $\mathrm{Mg}, \mathrm{Cu}, \mathrm{Zn}, \mathrm{Pr}, \mathrm{Sm}, \mathrm{Ho}$ and $\mathrm{Er}$ are moderately enriched (5-10 times), while the remaining trace-elements show a slight $(<5$ times) enrichment. Trace-element concentrations in G3 veins are on average lower than in G2 veins. However, $\mathrm{G} 3$ vein concentrations of $\mathrm{S}, \mathrm{As}, \mathrm{Sr}, \mathrm{La}, \mathrm{Ce}, \mathrm{Eu}$ and $\mathrm{Pb}$ are weakly $(<2.7$ times) enriched or similar compared to G2 veins (Table 4). In addition, there is an observable enrichment trend in veins from distal through proximal to mineralization zone samples. The highest vein calcite trace-element concentrations are found in G2 veins in CM12-431.

REE concentrations normalized to Post-Archaean Australian Shale (PAAS; McLennan, 1989) show relatively similar values for light REE (LREE) and HREE, while in some veins Eu and sometimes also the neighbouring REE show a relative enrichment (Fig. 6). This enrichment is not systematic with respect to vein generation and distance to the mineralization zone. In contrast, absolute REE concentrations show systematic variations with respect to the vein paragenesis and distance from the mineralization zone. G2 veins from the mineralization zone show the highest REE concentrations and G2 veins are always enriched relative to G1 veins. However, REE concentrations in G2 veins from the Pozo Seco Zone mineralization (CM10-247) are similar to G1 veins from the Pegaso Zone mineralization and proximal and distal G2 veins, but are lower than most Pegaso Zone G2 veins (Figure 7).

\section{DISCUSSION}

\section{Correlation between the local, regional and global stable isotope background}

The least altered drill hole at Cinco de Mayo (CM09-94) shows average isotope ratios for Finlay limestone of $\delta^{13} \mathrm{C}=2.9 \pm 0.6 \%$ and $\delta^{18} \mathrm{O}=22.4 \pm 1.3 \%$. In comparison, global scale $\mathrm{C}$ and $\mathrm{O}$ isotope ratios of Cretaceous limestone range between $-5 \%$ and $5 \%$ for $\delta^{13} \mathrm{C}$ and $23 \%$ and $30 \%$ for $\delta^{18} \mathrm{O}$ (Veizer et al., 1999). While $\delta^{13} \mathrm{C}$ values of the least altered Finlay limestone are consistent with the global average $\left(\delta^{13} \mathrm{C}=2.4 \%\right.$ ), $\delta^{18} \mathrm{O}$ is considerably depleted (global average $\delta^{18} \mathrm{O}=27.7 \%$ ). This shift in $\delta^{18} \mathrm{O}$ values suggests isotope exchange on a scale larger than the alteration associated with mineralization at Cinco de Mayo, i.e. on a regional scale. The presence of G1 veins that show evidence for ductile deformation (folded, boudinaged) and an isotope composition similar to the local least altered limestone suggests that the shift to lower $\delta^{18} \mathrm{O}$ took place during carbonate diagenesis. 
Megaw (1990) reported stable isotope ratios for barren Finlay limestone from the Santa Eulalia mining district, $\sim 250 \mathrm{~km}$ to the $\mathrm{S}$ of Cinco de Mayo, that are $-0.8 \%$ o for $\delta^{13} \mathrm{C}$ and $21.8 \%$ o for $\delta^{18} \mathrm{O}$. (Sweeney, 1987) reported $\delta^{13} \mathrm{C}$ values of $1 \%$ and $\delta^{18} \mathrm{O}$ values of $18 \%$ for unaltered Finlay limestone from the Naica district, $\sim 350 \mathrm{~km}$ to the $\mathrm{S}$ of Cinco de Mayo. While there is general agreement between the three sites, stable isotope ratios of least altered limestone from Cinco de Mayo are slightly higher than those from Santa Eulalia and Naica. The reason for these slight differences may simply reflect heterogeneous alteration during carbonate diagenesis or weak alteration of distal rocks during mineralization at Santa Eulalia and Naica. The least altered Finlay samples used by Megaw (1990) to define the Santa Eulalia C and O isotope background were sampled at a distance of $\sim 5000 \mathrm{~m}$ from the mineralization zone. It can be speculated that this sample was exposed to distal stable isotope alteration despite the absence of visible mineralization given the size of previously documented ${ }^{18} \mathrm{O}$ alteration halos in carbonate rocks (Barker et al., 2013; Kesler et al., 1995). Further sampling of regional rocks thought to be unaffected by hydrothermal alteration would be needed to confidently establish a regional vs. local background. Here, we assume that the local $\delta^{18} \mathrm{O}$ background is $\sim 22 \%$.

\section{Constraints on the stable isotope composition and temperature of the mineralization fluid}

The decrease of vein and wall rock stable isotope ratios in the proximity to mineralization is consistent with isotope exchange reactions driven by an isotopically light fluid. The stable isotope composition of $\mathrm{G} 2$ vein calcite (frequently with sulfide minerals) from the mineralization zone can be taken as synchronous with sulfide precipitation and used to constrain the composition and source of the incoming mineralization fluid. G1 veins are likely related to diagenesis and G3 veins postdate mineralization and may represent late stage fluid flow or be completely unrelated. The composition of $\mathrm{G} 2$ veins from the mineralization zone clusters around $-1 \%$ or $\delta^{13} \mathrm{C}$ and $13 \%$ or for $\delta^{18} \mathrm{O}$ (Figs. 2, 3 and 5) and this composition in combination with fluid-calcite $\mathrm{O}$ isotope fractionation factors can be used to constrain the stable isotope composition of the vein forming and mineralizing fluid. However, the derived constraints are based on the assumption that isotopic equilibrium was attained during the alteration and are thus subject to uncertainty.

The mineralization temperature at Cinco de Mayo is unconstrained but a range of $250^{\circ} \mathrm{C}$ to $500^{\circ} \mathrm{C}$ is accepted for most carbonate hosted $\mathrm{Ag}-\mathrm{Pb}-\mathrm{Zn}-\mathrm{Cu}$ deposits in northern Mexico (Haynes and Kesler, 1988; Megaw et al., 1988). Adopting this temperature range and suitable calcite-fluid $\mathrm{O}$ isotope fractionation factors (Chacko et al., 2001) in combination with the measured $\mathrm{O}$ isotope ratio of vein calcite $(\sim 13 \%)$ indicate an $\mathrm{O}$ isotope ratio of the alteration fluid between $5.7 \%$ o $\left(250^{\circ} \mathrm{C}\right)$ and $11.2 \%$ o $\left(500^{\circ} \mathrm{C}\right)$. If it is assumed that the infiltrating fluid was magmatic $\left(\delta^{18} \mathrm{O}=7 \%\right.$ - 9\% ; Taylor, 1974), then the observed vein calcite $\delta^{18} \mathrm{O}$ values would be in equilibrium with magmatic fluid at temperatures between $\sim 290^{\circ} \mathrm{C}$ and $\sim 360^{\circ} \mathrm{C}$. Within the 
457 with a dominantly magmatic source for the mineralizing fluid. A similar conclusion was reached 458 for limestone alteration at Providencia, northern Mexico (Rye, 1966; Rye and O'Neil, 1968).

459

460

461

462

463

464

465

466

467

468

469

470

471

472

473

474

475

476

477

478

479

480

481

482

483

484

485

486

487

488

489

490

491

492

493

494

\section{Fluid flow model for isotope alteration}

Hydrothermal limestone alteration proceeds as dissolution-precipitation reaction allowing for isotope exchange between the solid and fluid. The intensity of stable isotope alteration and the propagation distance of the alteration front from the fluid inlet depend on the fluid volume, the relative difference in solid and fluid compositions, temperature, rates of fluid-mineral isotope exchange, and the transport mechanism. A conceptual, 1-dimensional reactive transport model for infiltration of an isotopically light, magmatic fluid into isotopically heavy limestone is shown in Figure 9. This model is only an approximation because the 1-dimensional flow vector cannot capture complex natural fluid dynamics resulting from heterogeneities in the aquifer permeability. Keeping these uncertainties in mind, the model provides a framework that allows relating the measured stable isotope composition of altered wall rock and vein samples to the progressively changing isotopic composition of the reactive alteration fluid. Rates of fluidmineral isotope exchange are related to transport rates using the dimensionless Damköhler number $\left(\mathrm{N}_{\mathrm{D}}=\right.$ reaction rate/transport rate). A high $\mathrm{N}_{D}\left(\mathrm{~N}_{\mathrm{D}} \geq \sim 10\right)$ indicates instantaneous reaction and transport limited reaction front propagation, whereas the isotope alteration front lags behind the fluid front at low $\mathrm{N}_{D}\left(\mathrm{~N}_{\mathrm{D}}<1\right)$. The dimensionless Peclet number describes the relative proportion of advective to diffusive isotope transport $\left(\mathrm{N}_{\mathrm{Pe}}=\right.$ advective transport rate/diffusive transport rate) and controls the sharpness of isotope ratio gradient along the flow path. The length scale of front propagation is a function of the total fluid volume involved in the alteration, expressed as time-integrated fluid flux (TIFF in $\mathrm{cm}^{3} / \mathrm{cm}^{2}$ ) reflecting the total fluid volume $\left(\mathrm{cm}^{3}\right)$ entering the aquifer per unit area $\left(\mathrm{cm}^{2}\right)$ at the fluid inlet. Details on the modelling approach can be found elsewhere (e.g., Bowman et al., 1994; Dipple and Ferry, 1992a; Knoop et al., 2002; Lassey and Blattner, 1988).

Near the fluid source, a large flux of externally buffered fluid that is compositionally distinct from the infiltrated limestone promotes pervasive wall rock alteration. If isotopic equilibrium is attained during wall rock alteration and vein calcite precipitation, both will have identical isotope ratios $\left(\triangle^{18} \mathrm{O}_{\mathrm{WR}-\mathrm{vein}} \approx 0\right)$ at low wall rock $\delta^{18} \mathrm{O}$ (Fig. 9A and $\left.\mathrm{B}\right)$. The isotope ratio of the alteration fluid will increase with distance to the fluid inlet as a result of isotope exchange reactions with the limestone wall rock and of mixing with pre-existing pore-fluid that is in equilibrium with the unaltered limestone and hence isotopically heavier than the incoming magmatic fluid. Thus, even pervasively altered distal rocks will be characterized by isotope ratios in between those near the fluid inlet and unaltered distal rocks. Progressive fluid-rock interaction along the flow path will shift the fluid isotope composition closer to its equilibrium value with the wall rocks and diminish its alteration capacity. Sluggish reaction kinetics will then produce vein calcite that is isotopically light relative to its moderately altered wall rock $\left(\triangle^{18} \mathrm{O}_{\mathrm{WR} \text {-vein }}>0\right)$ (Fig. 9A and B). When the alteration fluid composition approaches equilibrium with the 
495

limestone, vein calcite will be isotopically identical to its unaltered wall rock $\left(\triangle^{18} \mathrm{O}_{\mathrm{WR}-\mathrm{vein}}=0\right)$ at high wall rock $\delta^{18} \mathrm{O}$ (Fig. 9A and B). The position of this point in space defines the limit of the stable isotope alteration footprint. Scenarios for different values of $\mathrm{N}_{P e}$ and $\mathrm{N}_{\mathrm{D}}$ are shown in Figure 9.

$\Delta^{18} \mathrm{O}_{\mathrm{WR}-\mathrm{vein}}$ values of distal, proximal and mineralization zone samples display a positive correlation with $\delta^{18} \mathrm{O}_{\mathrm{WR}}$ (Fig. 10A), which is consistent with the conceptual model (Fig. 9). Mineralization zone samples are characterized by low $\Delta^{18} \mathrm{O}_{\mathrm{WR}-\mathrm{vein}}$ at low $\delta^{18} \mathrm{O}_{\mathrm{WR}}$, indicating proximity to the fluid inlet, whereas distal samples show low to intermediate $\Delta^{18} \mathrm{O}_{\mathrm{WR} \text {-vein values }}$ at high $\delta^{18} \mathrm{O}_{\mathrm{WR}}$. However, a number of samples display negative $\Delta^{18} \mathrm{O}_{\mathrm{WR} \text {-vein values and therefore }}$ appear inconsistent with the theory (Fig. 10A). Negative $\Delta^{18} \mathrm{O}_{\mathrm{WR}-\mathrm{vein}}$ values may result from erroneous vein generation classification, or represent a different snapshot of the same alteration event. Pulsed fluid supply and/or fracture healing and vein calcite formation at different times can form isotopically distinct veins representing the dynamically changing fluid composition during the alteration (see Bowman et al., 1994 for discussion). Continued wall rock alteration may then result in the observed negative $\Delta^{18} \mathrm{O}_{\mathrm{WR}-\text { vein }}$ values. The majority of seemingly inconsistent vein-wall rock pairs are from CM10-247 (Pozo Seco Zone) and comprise strongly altered wall rock and less depleted veins that are compositionally and texturally distinct from G1 veins. These samples are therefore indicative of early vein formation predating the final isotope alteration of the surrounding wall rock. This rationale also applies to samples from CM12-423 and CM12-431. Negative $\Delta^{18} \mathrm{O}_{\mathrm{WR}-\mathrm{vein}}$ values from CM09-89 represent isotopically heavy veins in slightly altered limestone wall rock. As for negative $\Delta^{18} \mathrm{O}_{\mathrm{WR}-\mathrm{vein}}$ values from the mineralization zone, isotopically heavy veins in CM09-89 may represent an early stage of vein formation. Alternatively, the veins may be diagenetic G1 veins that show textural characteristics of G2 veins (Fig. 10A).

Vein-wall rock pairs that appear to record the final alteration progress (i.e. positive $\left.\Delta^{18} \mathrm{O}_{\mathrm{WR}-\mathrm{vein}}\right)$ allow for the evaluation of fluid volume and reaction kinetics and can thus aid in interpreting individual samples within the context of the larger scale hydrothermal system. Figure $10 \mathrm{~B}$ shows vein-wall rock pairs with $\Delta^{18} \mathrm{O}_{\mathrm{WR}-\mathrm{vein}}>0$ together with contours outlining Damköhler numbers and the TIFF-normalized distance (distance/TIFF) from the fluid inlet. The volume of fluid (TIFF) driving the isotope alteration front is approximately proportional to its propagation distance from the source (Hofmann, 1972). Hence, pervasively altered mineralization zone samples plot at low z/TIFF values, whereas moderately altered proximal and distal samples plot at higher $\mathrm{z}$ /TIFF values. Figure 10B can be used to approximate the TIFF if the distance of the sample to the assumed fluid inlet is known. For example, $\Delta^{18} \mathrm{O}_{\mathrm{WR}-\text { vein }}$ and $\delta^{18} \mathrm{O}_{\mathrm{WR}}$ values of CM09-89 $(\mathrm{z}=\sim 10.6 \mathrm{~km})$ plot between 0.3 and 0.5 (Fig. 10B) suggesting a TIFF of $2.1 \times 10^{6}$ $\mathrm{cm}^{3} / \mathrm{cm}^{2}$ to $3.5 \times 10^{6} \mathrm{~cm}^{3} / \mathrm{cm}^{2}$. Flux estimates based on the composition and location of CM10292 and CM08-45 yield similar results. This estimate is consistent with crustal fluid flux during regional metasomatism and contact metamorphism (Ague, 1997; Dipple and Ferry, 1992b; Ferry and Dipple, 1991), including carbonate hosted systems (Ferry et al., 2002). Furthermore, the 
534 position of $\Delta^{18} \mathrm{O}_{\mathrm{WR}-\mathrm{vein}}$ vs. $\delta^{18} \mathrm{O}_{\mathrm{WR}}$ pairs in Figure 10B reflects the rate of isotope exchange 535 reactions between the fluid and wall rock along flow through the aquifer. Fast reactions result in $536 \triangle^{18} \mathrm{O}_{\text {WR-vein }}$ vs. $\delta^{18} \mathrm{O}_{\text {WR }}$ pairs plotting at high $\mathrm{N}_{\mathrm{D}}$, while sluggish reactions plot at low $\mathrm{N}_{\mathrm{D}}$ (Fig. 537 10B). Figure 10B therefore indicates changing reaction kinetics from fast within the 538 mineralization zone to sluggish in distal parts of the system, potentially related to fluid cooling 539 along its flow path.

540 In summary, the measured oxygen isotope composition of Cinco de Mayo wall rock and 541 vein calcite samples is consistent with a simple 1-dimensional fluid flow and alteration model 542 (Fig. 11A and B). CM09-94 represents the least altered background based on only a small 543 isotope ratio dispersion with depth, similar vein and wall rock compositions and the high wall 544 rock $\mathrm{O}$ isotope ratios. In most cases, proximal and mineralization zone samples show isotopically 545 depleted veins and relatively strong variations of depleted wall rock $\mathrm{O}$ isotope values. The 546 compositional variations between veins and wall rocks indicates that close to equilibrium 547 conditions have been reached locally (Fig. 10B); consistent with the presence of preferential fluid 548 pathways. CM09-89 represents the most distal part of the system where stable isotope alteration 549 is detectable and thus defines the extent of the stable isotope alteration footprint at $\sim 11 \mathrm{~km}$ from 550 the mineralization zone (Fig. 11A and B). The large size of this ${ }^{18} \mathrm{O}$ depletion halo may be 551 explained by the presence of a large fluid flow system requiring pore space connectivity on the $552 \mathrm{~km}$ scale or fluid infiltration into the Finlay Formation at multiple, potentially structurally 553 controlled, fluid inlets. However, the outlined consistency of the distribution of isotopic 554 alteration with a simple 1-dimensional flow system and the concentrated occurrence of hornfels 555 alteration and mineralization indicative of a localized heat and fluid source imply that large scale 556 limestone stable isotope alteration at Cinco de Mayo was facilitated by overall fluid connectivity.

\section{Correlation of vein calcite trace-element concentrations with stable isotope ratios}

The inverse correlation of vein calcite trace-element concentrations with respective $\mathrm{O}$ isotope ratios corroborates the link between mineral deposit formation and limestone stable isotope alteration. This correlation is most strongly developed for $\mathrm{Zn}, \mathrm{Mn}, \mathrm{As}, \mathrm{Fe}, \mathrm{Y}$ and $\mathrm{Pb}$ concentrations. Despite considerable spread even on the per-vein basis, trace-element concentrations in mineralization zone G2 veins from cores CM12-431 (and sometimes also CM12-423) are typically two orders of magnitude higher than in G1 veins and distal G2 veins. However, mineralization zone hole CM11-380 shows both low $\delta^{18} \mathrm{O}_{\text {vein }}$ and trace-element concentrations (Fig. 8; Table 4). Trace-element enrichment in G2 veins, particularly within the mineralization zone is consistent with their strong fluorescence under UV light. Manganese substitution is a common cause of fluorescence in carbonates together with other activators including REEs, Zn and lattice defects (Gies, 1975; Schulman et al., 1947). The high Fe concentration in $\mathrm{G} 2$ veins is consistent with the presence of abundant ankerite (Table 4). 
REE concentrations and their ratios including $\mathrm{Ce}_{\mathrm{N}} / \mathrm{Ce}_{\mathrm{N}}{ }^{*}$ and $\mathrm{Eu}_{\mathrm{N}} / \mathrm{Eu}_{\mathrm{N}}{ }^{*}$ appear to vary nonsystematically with position along the hydrothermal flow path, vein generation and $\delta^{18} \mathrm{O}_{\text {vein }}$ (Fig.

572 8). However, the G3 vein in CM12-431 shows significantly elevated $\mathrm{La} / \mathrm{Nd}, \mathrm{La} / \mathrm{Yb}, \mathrm{Eu}_{\mathrm{N}} / \mathrm{Eu}_{\mathrm{N}}{ }^{*}$ 573 and low $\mathrm{Ce}_{\mathrm{N}} / \mathrm{Ce}_{\mathrm{N}}{ }^{*}$ compared to all other analyzed veins. This vein has also the lowest $\delta^{18} \mathrm{O}$ value, 574 which corroborates the distinction of G3 veins as individual group. Figure 6 shows that a positive $575 \mathrm{Eu}$-anomaly has preferentially developed in G2 veins relative to G1 veins from the same hole. 576 For example, G1 veins from CM12-431, CM12-423 and CM06-01 show no or only a weak Euanomaly, whereas $\mathrm{G} 2$ veins from these holes show a distinct $\mathrm{Eu}$-anomaly with the exception of one G2 vein in CM12-423 (Fig. 6). Generally, the relatively flat REE pattern of vein calcite may result from the presence of excess $\mathrm{Ca}^{2+}$ relative to $\mathrm{CO}_{3}{ }^{2-}$ in the alteration fluid. Calcite preferentially incorporates $\mathrm{Eu}^{3+}$ and the Eu-anomaly present in only some of the $\mathrm{G} 2$ veins may indicate their formation prior to $\mathrm{G} 2$ veins lacking the Eu-anomaly, which may be related to cooling-induced reduction of $\mathrm{Eu}^{3+}$ and/or decreased ligand concentrations $\left(\mathrm{CO}_{3}{ }^{2-}, \mathrm{HCO}_{3}^{-}, \mathrm{F}^{-}\right)$ (Bau, 1991). The relatively low $\mathrm{Ce}_{\mathrm{N}} / \mathrm{Ce}_{\mathrm{N}}{ }^{*}(\sim 0.75)$ in $\mathrm{G} 3$ vein calcite from $\mathrm{CM} 12-431$ suggests reducing conditions of late stage fluid, which may be unrelated to mineralization but is consistent with cooling of the system during or after mineralization (Bau and Möller, 1992).

\section{Implications and application of carbon and oxygen isotopes to mineral exploration}

The results of this study show that stable isotope analysis of vein and wall rock carbonate provides insight into the nature and extent of hydrothermal systems. Detailed analysis of vein samples and vein-wall rock pairs appear to have promise for mineral deposit vectoring. The offset between the global isotopic reference frame and the inferred least altered samples at Cinco de Mayo and other deposits (cf. Santa Eulalia, Naica, Providencia) underscores the need during mineral exploration stable isotope programs for defining the local background against which mineralization-related changes in stable isotope ratios can be compared. Relative to global values, the least altered samples may appear strongly altered but that shift in stable isotope ratios is likely unrelated to mineralization and therefore may be misleading. This can be achieved by taking several tens of samples per limestone unit at progressive distances sufficiently far away from the assumed center of mineralization $(>10 \mathrm{~km})$ to avoid distal intrusion-related alteration. Once the extent of the isotope alteration halo is established, preferential fluid flow paths can be delineated by systematic high resolution sampling at $\sim 5-10 \mathrm{~m}$ depth intervals of 1 to 3 complete drill holes from within the alteration halo. Additional sampling may then target vein-wall pairs from the aquifer every $2-3 \mathrm{~km}$ at coarser spacing of $\sim 10$ pairs per drill hole, depending on aquifer thickness. These will reveal isotopic gradients that vector towards mineralization and reflect the alteration intensity and fluid volumes involved (Fig. 10). Large ore deposits are unlikely to form from small fluid volumes, so constraining the volume of alteration fluids is important because large-scale pervasive isotope alteration requires a large fluid flux, which in turn increases the likelihood for larger volumes of contained metal (Waring et al., 1998). Oxygen isotope ratios and particularly those of vein carbonate show stronger gradients between 
mineralization zone and unaltered distal rocks and will therefore provide a clearer signal of this mineralization-related fluid flow (Fig. 11).

Classification of different vein generations based only on textural observations aided by UV fluorescence studies is time-effective and provides an independent tool to distinguish significant from unimportant and unrelated veins. Vein carbonate stable isotope ratios can be combined with trace-element analysis (As, Fe, Mn, Zn, La, Ce, Pr, Sm, Eu, Gd) of select samples to evaluate different vein types for their metal concentrations and constrain redox conditions of the vein forming fluid. In addition, it is possible that portable XRF analysis of carbonate veins may be useful to help further characterize carbonate vein chemistry (Andrew and Barker, 2017) and aid in identifying and discriminating vein generations. The method of isotopic analysis employed here, incorporating sampling using a handheld drill followed by laser spectrometry analysis represents an adequate approach to achieve the required sample throughput rate in mineral exploration programs. The robustness and simple operation of available ICOS isotope analyzers are beneficial for this application and allow real-time stable isotope analyses during core logging on site. Indeed, the low power and consumable requirements mean that the analytical setup utilised for this study could be easily deployed in a core shed (or even in a fly camp) setting if needed for rapid data turnaround.

\section{CONCLUSIONS}

Formation of the Cinco de Mayo $\mathrm{Zn}-\mathrm{Ag}$ deposit was accompanied by extensive stable isotope alteration of the host limestone formations. This alteration is best developed in the Middle Albian Finlay Formation, which was the major aquifer for the hydrothermal mineralization fluid. The stable isotope composition of pervasively altered holes intersecting the Pegaso Zone mineralization indicates hydrothermal fluid flow also crossed formation boundaries for $\sim 200 \mathrm{~m}$ into the underlying Lagrima and Benigno Formations. Hydrothermal limestone alteration resulted in an overall shift of average wall rock stable isotope ratios to values lower than in the least altered distal hole (CM09-94) as well as strongly erratic stable isotope ratios of individual samples that vary up to $10 \%$ over depth intervals of $10 \mathrm{~m}$ and less. Based on macroscopic textural observations of calcite veins and their stable isotope composition, three different vein generations can be identified, which represent fluid flow during limestone diagenesis and during and after mineralization, respectively. The stable isotope composition of syn-mineralization veins and their wall rocks is consistent with an advection-dominated reactive flow model and isotope exchange during mineral dissolution-precipitation reactions driven by a large flux of high-temperature magmatic fluid. The correlation of vein calcite trace-element concentrations with stable isotope ratios corroborates their classification as pre-, syn-, and postmineral fluid pathways. The highly variable limestone wall rock stable isotope composition in the mineralization zone and the existence of wall rock samples that are isotopically depleted relative to adjacent syn-mineralization veins imply that fluid flow was locally channelized and aided by brittle deformation. Overall, the lateral extent of detectable stable isotope alteration in 
646 proximal and distal holes for up to $10.6 \mathrm{~km}$ away from the Pegaso Zone mineralization along 647 strike of the Finlay Formation defines the size of the stable isotope footprint of the Cinco de 648 Mayo $\mathrm{Zn}-\mathrm{Ag}$ deposit. Combining this with zoning and variability of stable isotope results 649 indicates that stable isotope studies can aid mineral exploration programs: 1) By defining the 650 magnitude of the overall system, 2) As a vectoring tool and 3) To identify pathways 651 preferentially followed by the hydrothermal fluids, which may also represent sites for metal 652 accumulation. An example of the practical application of these results is the strong indication that 653 additional exploration potential exists near proximal hole CM08-45 because its degree of stable 654 isotope alteration is comparable to mineralization zone samples. In addition, the lack of stable 655 isotope ratio transition from altered to background values with depth in CM10-247 suggests that 656 alteration and perhaps mineralization extend to levels deeper than captured by exploration 657 drilling.

\section{ACKOWLEDGEMENTS}

We are grateful to C. Raley and B. Neumann for assistance during laboratory stable isotope 660 analyses. This research has been funded through a MITACS Elevate fellowship to A.B., MAG 661 Silver Corp., and ALS Canada Ltd.

662 
664 Fig. 1 Geological map of the Cinco de Mayo property showing the location of investigated drill 665 holes and surface projection of the Pegaso Zone and Pozo Seco Zone mineralization.

666 Fig. 2 Downhole $\mathrm{O}$ and $\mathrm{C}$ isotope ratios in wall rock and vein calcite samples from (A) the least 667 altered hole (CM09-94) and (B) the mineralization zone (CM12-431). The brown dashed line 668 represents the five-point moving average for wall rock $\delta^{18} \mathrm{O}$ and $\delta^{13} \mathrm{C}$ values. The bulk rock $\mathrm{Ag}$ 669 concentration (ppm; secondary abscissa) is displayed as a proxy for mineralization.

670 Fig. 3 Box plots for Finlay Formation (A) limestone wall rock and (B) G2 veins plotted in the 671 order of increasing distance from CM12-431. CM12-431 was chosen as the origin based on the 672 presence of hornfels, skarn and strong mineralization. CM10-247 intersects the Pozo Seco Zone 673 mineralization and is plotted to the left of CM12-431. The span of the boxes represents the 674 composition of $50 \%$ of the data population (interquartile range), the band within the box 675 represents the median and the dot is the mean. The whisker length is 1.5 times the interquartile 676 range; crosses define the $1 \%$ and $99 \%$ interval.

677 Fig. 4 Mosaic showing representative normal and UV light images of the different vein 678 generations in half core samples together with measured $\mathrm{O}$ and $\mathrm{C}$ isotope ratios. Note the yellow 679 color of vein carbonate in G2 veins in CM12-431 indicating the presence of ankerite.

680 Fig. $5 \delta^{13} \mathrm{C}$ vs $\delta^{18} \mathrm{O}$ data of the different calcite vein generations at Cinco de Mayo. Vein 681 classification is based only on macroscopic textural observations but is consistent with distinct 682 stable isotope compositions. Classification of G2a and G2b veins is based on cross-cutting 683 relationships between veins that are both texturally consistent with generation 2 veins. G2b veins 684 are always younger than $\mathrm{G} 2 \mathrm{a}$ veins.

685 Fig. 6 PAAS-normalized vein calcite REE pattern from the three vein generations in 686 mineralization zone, proximal and distal samples. REE concentrations are average values 687 calculated from the concentration of several laser ablation spots in each vein type per sample.

688 Fig. 7 Vein calcite $\mathrm{Nd}$ concentrations plotted against $\delta^{18} \mathrm{O}$ for the three vein generations in 689 mineralization zone, proximal and distal samples. The spread in $\mathrm{Nd}$ concentrations reflects the 690 per-vein compositional heterogeneity.

691 Fig. 8 Box plots showing the spread in select trace metal concentrations and ratios plotted against 692 vein calcite $\delta^{18} \mathrm{O}$ for the three vein generations in mineralization zone, proximal and distal holes.

693 Fig. 9 Conceptual 1-dimensional model of fluid flow and stable isotope alteration in limestone 694 during infiltration of magmatic fluid. The composition of altered wall rock (solid lines) and 695 coexisting veins (stippled lines) are shown for different Damköhler and Peclet numbers. The 696 input fluid $\delta^{18} \mathrm{O}$ composition (9\%) is consistent with a magmatic fluid, the initial wall rock $\delta^{18} \mathrm{O}$ 
697 composition represents the stable isotope background (22.5\%o) in CM09-94. Fluid transport is 698 from left to right. The fluid-calcite oxygen isotope fractionation factor (Chacko et al., 2001) is 699 calculated for an assumed temperature of $360^{\circ} \mathrm{C}$ (see text for discussion). (A) Wall rock and vein $700 \delta^{18} \mathrm{O}$ composition as a function of distance from the fluid inlet, showing the shape of the 701 alteration front in wall rock and vein samples for different fluid transport scenarios. (B) 702 Compositional difference between wall rock and vein $\left(\Delta^{18} \mathrm{O}_{\mathrm{WR}-\mathrm{vein}}\right)$ for the fluid transport 703 scenarios shown in (A) as a function of distance from the fluid inlet. (C) $\Delta^{18} \mathrm{O}_{\mathrm{WR}-\text { vein }}$ plotted 704 against $\delta^{18} \mathrm{O}_{\mathrm{WR}}$ for the different cases shown in (A) and (B).

705 Fig. $10 \Delta^{18} \mathrm{O}_{\mathrm{WR}-\mathrm{vein}}$ vs. $\delta^{18} \mathrm{O}_{\mathrm{WR}}$ values of mineralization zone, proximal and distal samples. (A) 706 All data including negative $\Delta^{18} \mathrm{O}_{\mathrm{WR}-\mathrm{vein}}$ values representing incomplete wall rock alteration (see 707 text for discussion). (B) $\Delta^{18} \mathrm{O}_{\mathrm{WR}-\text { vein }}$ vs. $\delta^{18} \mathrm{O}_{\mathrm{WR}}$ pairs shown for $\Delta^{18} \mathrm{O}_{\mathrm{WR}-\mathrm{vein}}>0$ using G2 veins 708 from the Finlay Formation only. The contour lines represent distance-normalized time709 integrated fluid flux (stippled lines; z/TIFF) and Damköhler numbers (solid lines; $\mathrm{N}_{\mathrm{D}}$ ). Compare 710 with Figure 9C for the construction of the contour lines.

711 Fig. 11 Box plot showing the $\delta^{18} \mathrm{O}$ and $\delta^{13} \mathrm{C}$ composition of (A) Finlay wall rock and (B) vein 712 samples plotted as function of distance from CM12-431. The solid (wall rock) and stippled 713 (vein) lines in $\delta^{18} \mathrm{O}$ plots represent the best fit of the real data to the 1-dimensional transport 714 model shown in Fig. 9 using advection dominated fluid flow $\left(\mathrm{N}_{\mathrm{Pe}}=100\right)$ and Damköhler 715 numbers of 1.5 and 5. 


\section{REFERENCES}

Ague, J. J., 1997, Crustal mass transfer and index mineral growth in Barrow's garnet zone, northeast Scotland: Geology, v. 25, p. 73-76.

Andrew, B. S. and Barker, S. L. L., 2017, Determination of carbonate vein chemistry using portable X-ray fluorescence and its application to mineral exploration: Geochemistry: Exploration, Environment, Analysis.

Baer, D. S., Paul, J. B., Gupta, M., and O'Keefe, A., 2002, Sensitive absorption measurements in the near-infrared region using off-axis integrated cavity output spectroscopy: SPIE 4817, Diode Lasers and Applications in Atmospheric Sensing, 2002, p. 167-176.

Barker, S. L. L., Dipple, G. M., Dong, F., and Baer, D. S., 2011, Use of laser spectroscopy to measure the ${ }^{13} \mathrm{C} /{ }^{12} \mathrm{C}$ and ${ }^{18} \mathrm{O} /{ }^{16} \mathrm{O}$ compositions of carbonate minerals: Analytical Chemistry, v. 83, p. 2220-2226.

Barker, S. L. L., Dipple, G. M., Hickey, K. A., Lepore, W. A., and Vaughan, J. R., 2013, Applying stable isotopes to mineral exploration: teaching an old dog new tricks: Economic Geology, v. 108, p. 1-9.

Bau, M., 1991, Rare-earth element mobility during hydrothermal and metamorphic fluid-rock interaction and the significance of the oxidation state of europium: Chemical Geology, v. 93, p. 219-230.

Bau, M. and Möller, P., 1992, Rare earth element fractionation in metamorphogenic hydrothermal calcite, magnesite and siderite: Mineralogy and Petrology, v. 45, p. 231246.

Beinlich, A., Barker, S. L. L., Dipple, G. M., Gupta, M., and Baer, D. S., 2017, Stable isotope $\left(\delta^{13} \mathrm{C}, \delta^{18} \mathrm{O}\right)$ analysis of sulfide-bearing carbonate samples using laser absorption spectrometry: Economic Geology, v. 112, p. 693-700.

Bowman, J. R., Willett, S. D., and Cook, S. J., 1994, Oxygen isotopic transport and exchange during fluid-flow: one-dimensional models and applications: American Journal of Science, v. 294, p. 1-55.

Camprubi, A., Gonzalez-Partida, E., and Iriondo, A., 2006, Mineralizing fluids of the shallow epithermal Au-Ag deposits of the El Barqueno district, Jalisco, Mexico: Journal of Geochemical Exploration, v. 89, p. 39-44.

Cathles, L. M., 1993, Oxygen isotope alteration in the Noranda mining district, Abitibi greenstone belt, Quebec: Economic Geology, v. 88, p. 1483-1511.

Chacko, T., Cole, D. R., and Horita, J., 2001, Equilibrium oxygen, hydrogen and carbon isotope fractionation factors applicable to geologic systems: Stable Isotope Geochemistry, v. 43, p. 1-81.

Clark, K. F. and de la Fuente L, F. E., 1978, Distribution of mineralization in time and space in Chihuahua, Mexico: Mineralium Deposita, v. 13, p. 27-49.

Criss, R. E., Champion, D. E., and Mcintyre, D. H., 1985, Oxygen isotope, aeromagnetic, and gravity-anomalies associated with hydrothermally altered zones in the Yankee Fork mining district, Custer County, Idaho: Economic Geology, v. 80, p. 1277-1296.

Criss, R. E., Singleton, M. J., and Champion, D. E., 2000, Three-dimensional oxygen isotope imaging of convective fluid flow around the Big Bonanza, Comstock lode mining district, Nevada: Economic Geology and the Bulletin of the Society of Economic Geologists, v. 95, p. 131-142.

Cumming, G. L., Kesler, S. E., and Krstic, D., 1979, Isotopic composition of lead in Mexican mineral deposits: Economic Geology, v. 74, p. 1395-1407. 
Dilles, J. H., Solomon, G. C., Taylor, H. P., and Einaudi, M. T., 1992, Oxygen and hydrogen isotope characteristics of hydrothermal alteration at the Ann-Mason porphyry copper deposit, Yerington, Nevada: Economic Geology, v. 87, p. 44-63.

Dipple, G. M. and Ferry, J. M., 1992a, Fluid flow and stable isotopic alteration in rocks at elevated temperatures with applications to metamorphism: Geochimica et Cosmochimica Acta, v. 56, p. 3539-3550.

Dipple, G. M. and Ferry, J. M., 1992b, Metasomatism and fluid-flow in ductile fault zones: Contributions to Mineralogy and Petrology, v. 112, p. 149-164.

Ewers, G. R., Mackenzie, D. E., Wyborn, D., Oversby, B. S., McPhie, J., and Andrews, A. S., 1994, Regional ${ }^{18} \mathrm{O}$ depletions in igneous rocks from the northern Drummond Basin, Queensland, Australia, and their implications for epithermal gold mineralization: Economic Geology and the Bulletin of the Society of Economic Geologists, v. 89, p. 662673.

Faure, G. and Mensing, T. M., 2005, Isotopes: principles and applications, Wiley.

Ferry, J. M. and Dipple, G. M., 1991, Fluid-flow, mineral reactions, and metasomatism: Geology, v. 19, p. 211-214.

Ferry, J. M., Wing, B. A., Penniston-Dorland, S. C., and Rumble, D., 2002, The direction of fluid flow during contact metamorphism of siliceous carbonate rocks: new data for the Monzoni and Predazzo aureoles, northern Italy, and a global review: Contributions to Mineralogy and Petrology, v. 142, p. 679-699.

Frimmel, H. E., 1992, Isotopic fronts in hydrothermally mineralized carbonate rocks: Mineralium Deposita, v. 27, p. 257-267.

Gies, H., 1975, Activation possibilities and geochemical correlations of photoluminescing carbonates, particularly calcites: Mineralium Deposita, v. 10, p. 216-227.

Haenggi, W. T., 2002, Tectonic history of the Chihuahua trough, Mexico and adjacent USA, Part II: Mesozoic and Cenozoic: Boletin de la Sociedad Geologica Mexicana, v. 55, p. 38-94.

Handschy, J. W. and Dyer, R., 1987, Polyphase deformation in Sierra del Cuervo, Chihuahua, Mexico: evidence for Ancestral Rocky Mountain tectonics in the Ouachita foreland of northern Mexico: Geological Society of America Bulletin, v. 99, p. 618-632.

Haynes, F. M. and Kesler, S. E., 1988, Compositions and sources of mineralizing fluids for chimney and manto limestone-replacement ores in Mexico: Economic Geology, v. 83, p. 1985-1992.

Hellstrom, J., Paton, C., Woodhead, J., and Hergt, J., 2008, Iolite: software for spatially resolved LA-(quad and MC) ICP-MS analysis: Mineralogical Association of Canada short course series, v. 40, p. 343-348.

Hewitt, W. P., 1966, Geology and mineralization of the main mineral zone of the Santa Eulalia district, Chihuahua, Mexico: Boletin de la Sociedad Geologica Mexicana, v. 29, p. 69147.

Hickey, K. A., Ahmed, A. D., Barker, S. L. L., and Leonardson, R., 2014, Fault-controlled lateral fluid flow underneath and into a Carlin-type gold deposit: isotopic and geochemical footprints: Economic Geology, v. 109, p. 1431-1460.

Hofmann, A., 1972, Chromatographic theory of infiltration metasomatism and its application to feldspars: American Journal of Science, v. 272, p. 69-90.

Hu, Z. C., Gao, S., Liu, Y. S., Hu, S. H., Chen, H. H., and Yuan, H. L., 2008, Signal enhancement in laser ablation ICP-MS by addition of nitrogen in the central channel gas: Journal of Analytical Atomic Spectrometry, v. 23, p. 1093-1101. 
Jamtveit, B., Grorud, H. F., and Bucher-Nurminen, K., 1992, Contact metamorphism of layered carbonate-shale sequences in the Oslo Rift. II: Migration of isotopic and reaction fronts around cooling plutons: Earth and Planetary Science Letters, v. 114, p. 131-148.

Kelley, D. L., Kelley, K. D., Coker, W. B., Caughlin, B., and Doherty, M. E., 2006, Beyond the obvious limits of ore deposits: the use of mineralogical, geochemical, and biological features for the remote detection of mineralization: Economic Geology, v. 101, p. 729752.

Kesler, S. E., Vennemann, T. W., Vazquez, R., Stegner, D. P., and Frederickson, G. C., 1995, Application of large-scale oxygen isotope haloes to exploration for chimney-manto $\mathrm{Pb}$ Zn-Cu-Ag deposits, in Coyner, A. R., and Fahey, P. L., eds., Geology and ore deposits of the American Cordillera: Reno, Geological Society of Nevada, p. 1383-1396.

Knoop, S. R., Kennedy, L. A., and Dipple, G. M., 2002, New evidence for syntectonic fluid migration across the hinterland-foreland transition of the Canadian Cordillera: Journal of Geophysical Research: Solid Earth, v. 107, p. ETG 6-1-ETG 6-25.

Large, R. R., Bull, S. W., and Winefield, P. R., 2001, Carbon and Oxygen Isotope Halo in Carbonates Related to the McArthur River (HYC) Zn-Pb-Ag Deposit, North Australia:Implications for Sedimentation, Ore Genesis, and Mineral Exploration: Economic Geology, v. 96, p. 1567-1593.

Lassey, K. R. and Blattner, P., 1988, Kinetically controlled oxygen isotope exchange between fluid and rock in one-dimensional advective flow: Geochimica et Cosmochimica Acta, v. 52, p. 2169-2175.

Longerich, H. P., Jackson, S. E., and Gunther, D., 1996, Laser ablation inductively coupled plasma mass spectrometric transient signal data acquisition and analyte concentration calculation: Journal of Analytical Atomic Spectrometry, v. 11, p. 899-904.

Lyons, J. I., 2008, Cinco de Mayo, Chihuahua, Mexico Stratigraphy. Private report for MAG Silver Corp. July 3, 2008.

MacInnis, D., 2009, MAG Silver discovers high grade molybdenum with gold at Cinco De Mayo, MAG Silver News Releases, September 23, 2009.

MacInnis, D., 2010, Cinco De Mayo September 30, 2010 management discussion and analysis ("MD\&A") excerpt, with full assay table and illustrative map, MAG Silver News Releases, November 10, 2010.

MacInnis, D., 2012, MAG Silver drills 61.6 metre silver, gold, zinc, lead, copper massive sulphide intercept at Cinco de Mayo, MAG Silver News Releases, July 18, 2012.

McDowell, F. W. and Keizer, R. P., 1977, Timing of mid-Tertiary volcanism in the Sierra Madre Occidental between Durango City and Mazatlan, Mexico: Geological Society of America Bulletin, v. 88, p. 1479-1487.

McLennan, S. M., 1989, Rare earth elements in sedimentary rocks; influence of provenance and sedimentary processes: Reviews in Mineralogy and Geochemistry, v. 21, p. 169-200.

Megaw, P., MacGlasson, J. A., Lyons, J. I., Hansen, L. D., and MacInnis, D. T., 2014, Blind Ag$\mathrm{Pb}-\mathrm{Zn}$ and Au-Mo discoveries in MAG Silver's Cinco de Mayo Mega-System, Chihuahua, Mexico SEG 2014: Keystone, Colorado.

Megaw, P. K. M., Barton, M. D., and Falce, J. I., 1996, Carbonate-hosted lead-zinc (Ag, Cu, Au) deposits of northern Chihuahua, Mexico, in Sangster, D. F., ed., Carbonate-Hosted LeadZinc Deposits: $75^{\text {th }}$ Anniversary Volume, Society of Economic Geologists.

Megaw, P. K. M., Ruiz, J., and Titley, S. R., 1988, High-temperature, carbonate-hosted Ag-Pb$\mathrm{Zn}(\mathrm{Cu})$ deposits of northern Mexico: Economic Geology, v. 83, p. 1856-1885. 
Megaw, P. K. N., 1990, Geology and geochemistry of the Santa Eulalia mining district, Chihuahua, Mexico, The University of Arizona.

Millonig, L. J., Beinlich, A., Raudsepp, M., Devine, F., Archibald, D. A., Linnen, R. L., and Groat, L. A., 2017, The Engineer Mine, British Columbia: An example of epithermal Au$\mathrm{Ag}$ mineralization with mixed alkaline and subalkaline characteristics: Ore Geology Reviews, v. 83, p. 235-257.

Muehlberger, W. R., 1993, Tectonic map of North America: southwest and southeast sheets. A user's guide, American Association of Petroleum Geologists.

Müller, W., Shelley, M., Miller, P., and Broude, S., 2009, Initial performance metrics of a new custom-designed ArF excimer LA-ICPMS system coupled to a two-volume laser-ablation cell: Journal of Analytical Atomic Spectrometry, v. 24, p. 209-214.

Murakami, H. and Nakano, T., 1999, Hydrothermal alteration of limestone and mineral exploration of $\mathrm{Zn}-\mathrm{Pb}$ skarn deposits in the Sako-nishi area of the Kamioka Mine, Central Japan: Resource Geology, v. 49, p. 259-280.

Naito, K., Fukahori, Y., He, P. M., Sakurai, W., Shimazaki, H., and Matsuhisa, Y., 1995, Oxygen and carbon isotope zonations of wall rocks around the Kamioka Pb-Zn skarn deposits, central Japan: application to prospecting: Journal of Geochemical Exploration, v. 54, p. 199-211.

Nieto-Samaniego, Á. F., Ferrari, L., Alaniz-Alvarez, S. A., Labarthe-Hernández, G., and RosasElguera, J., 1999, Variation of Cenozoic extension and volcanism across the southern Sierra Madre Occidental volcanic province, Mexico: Geological Society of America Bulletin, v. 111, p. 347-363.

Robertson, K. and Megaw, P., 2009, Cinco de Mayo: A new silver, lead, and zinc discovery in northern Mexico: The Leading Edge, v. 28, p. 730-735.

Ruiz, J., Patchett, P. J., and Ortega-Gutierrez, F., 1988, Proterozoic and Phanerozoic basement terranes of Mexico from Nd isotopic studies: Geological Society of America Bulletin, v. 100, p. 274-281.

Rye, R. O., 1966, The carbon, hydrogen, and oxygen isotopic composition of the hydrothermal fluids responsible for the lead-zinc deposits at Providencia, Zacatecas, Mexico: Economic Geology, v. 61, p. 1399-1427.

Rye, R. O. and O'Neil, J. R., 1968, $\mathrm{O}^{18}$ content of water in primary fluid inclusions from Providencia north-central Mexico: Economic Geology, v. 63, p. 232-238.

Schulman, J. H., Evans, L. W., Ginther, R. J., and Murata, K. J., 1947, The sensitized luminescence of manganese-activated calcite: Journal of Applied Physics, v. 18, p. 732739.

Selway, J. and Leonard, B., 2008, Independent technical report - Cinco de Mayo, Mexico, Caracle Creek International Consulting Inc.

Sweeney, R. L., 1987, Stable isotope geochemistry of calcite and limestone at Naica, Chihuahua, Mexico, University of Arizona, $51 \mathrm{p}$.

Taylor, H. P., 1974, Application of oxygen and hydrogen isotope studies to problems of hydrothermal alteration and ore deposition: Economic Geology, v. 69, p. 843-883.

Taylor, H. P., 1979, Oxygen and hydrogen isotope relationships in hydrothermal mineral deposits, in Barnes, H. L., ed., Geochemistry of Hydrothermal Ore Deposits, 2nd ed.: New York, Wiley, p. 236-277. 
Taylor, H. P., 1997, Oxygen and hydrogen isotope relationships in hydrothermal mineral deposits, in Barnes, H. L., ed., Geochemistry of Hydrothermal Ore Deposits, 3rd ed.: New York, Wiley, p. 229-302.

Taylor, H. P. and Epstein, S., 1963, $\mathrm{O}^{18} / \mathrm{O}^{16}$ ratios in rocks and coexisting minerals of the Skaergaard Intrusion, east Greenland: Journal of Petrology, v. 4, p. 51-74.

Vazquez, R., Vennemann, T. W., Kesler, S. E., and Russell, N., 1998, Carbon and oxygen isotope halos in the host limestone, El Mochito $\mathrm{Zn}-\mathrm{Pb}-(\mathrm{Ag})$ skarn massive sulfide-oxide deposit, Honduras: Economic Geology and the Bulletin of the Society of Economic Geologists, v. 93, p. 15-31.

Veizer, J., Ala, D., Azmy, K., Bruckschen, P., Buhl, D., Bruhn, F., Carden, G. A. F., Diener, A., Ebneth, S., Godderis, Y., Jasper, T., Korte, C., Pawellek, F., Podlaha, O. G., and Strauss, H., $1999,{ }^{87} \mathrm{Sr} /{ }^{86} \mathrm{Sr}$, delta $\delta^{13} \mathrm{C}$ and $\delta^{18} \mathrm{O}$ evolution of Phanerozoic seawater: Chemical Geology, v. 161, p. 59-88.

Velador, J. M., Heizler, M. T., and Campbell, A. R., 2010, Timing of magmatic activity and mineralization and evidence of a long-lived hydrothermal system in the Fresnillo silver district, Mexico: Constraints from ${ }^{40} \mathrm{Ar} /{ }^{39} \mathrm{Ar}$ geochronology: Economic Geology, v. 105, p. $1335-1349$.

Waring, C. L., Andrew, A. S., and Ewers, G. R., 1998, Use of O, C, and S stable isotopes in regional mineral exploration AGSO Journal of Australian Geology \& Geophysics, v. 17, p. 301-313. 
Figure 1

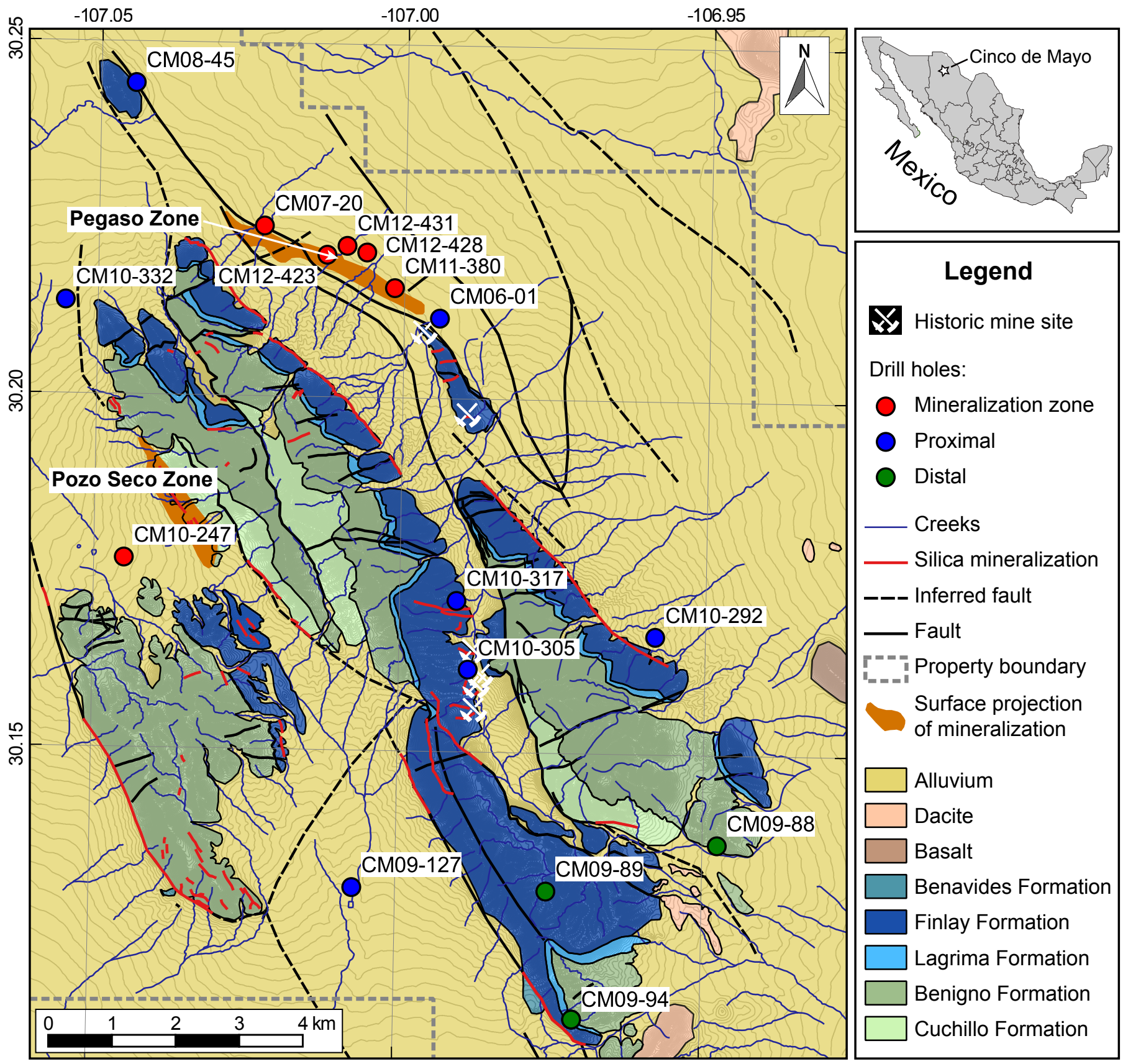


Figure 2

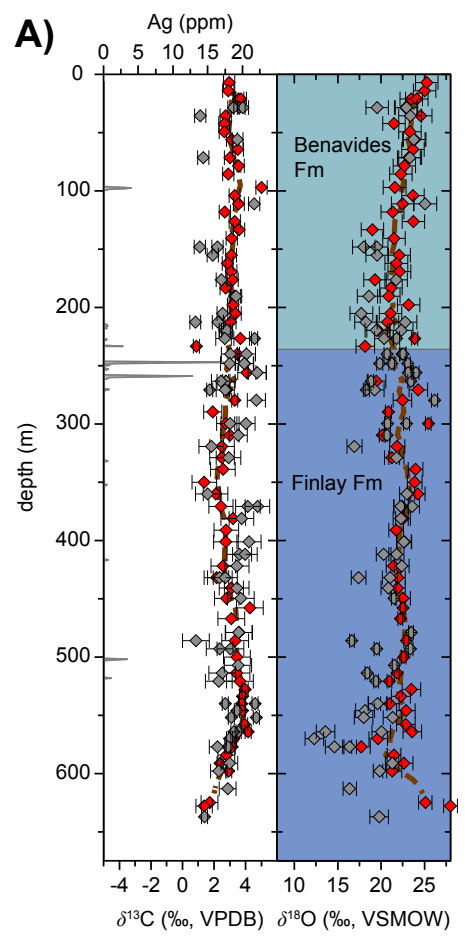

B) $\quad \begin{array}{ll}\mathrm{Ag}(\mathrm{ppm}) \\ 50 \quad 100\end{array}$

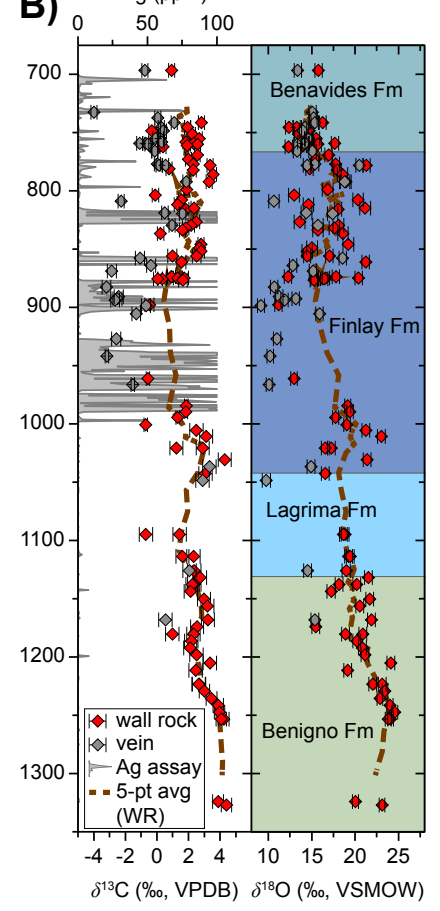


Figure 3

\section{A) Finlay wall rock}
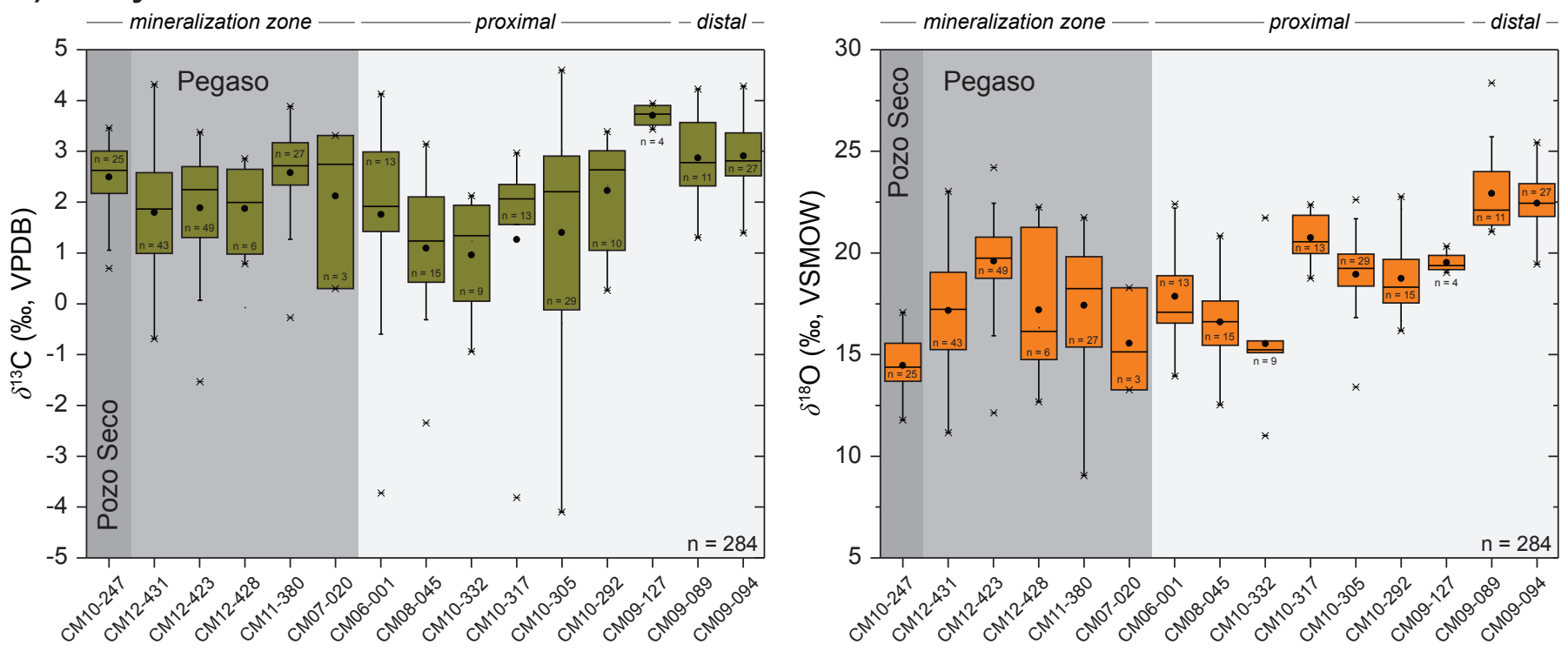

\section{B) Finlay G2 veins}
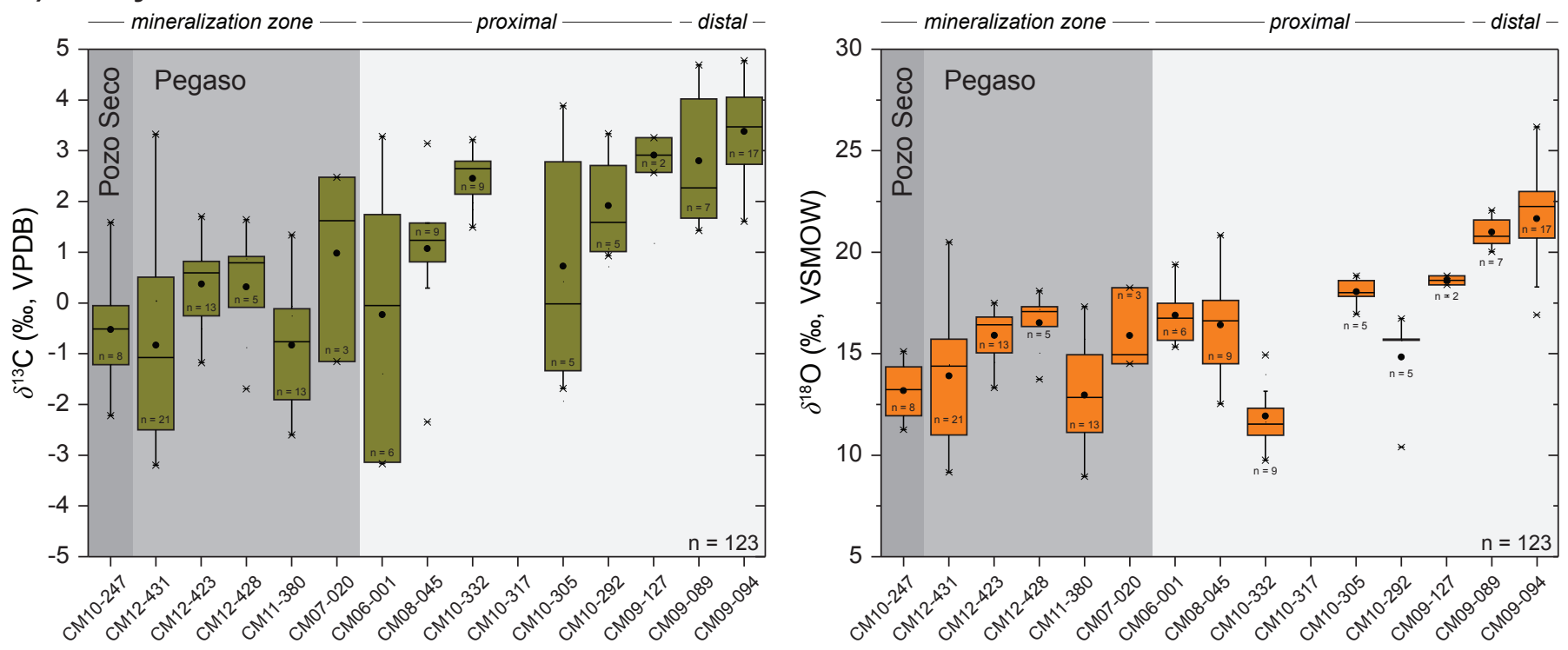
Figure 4
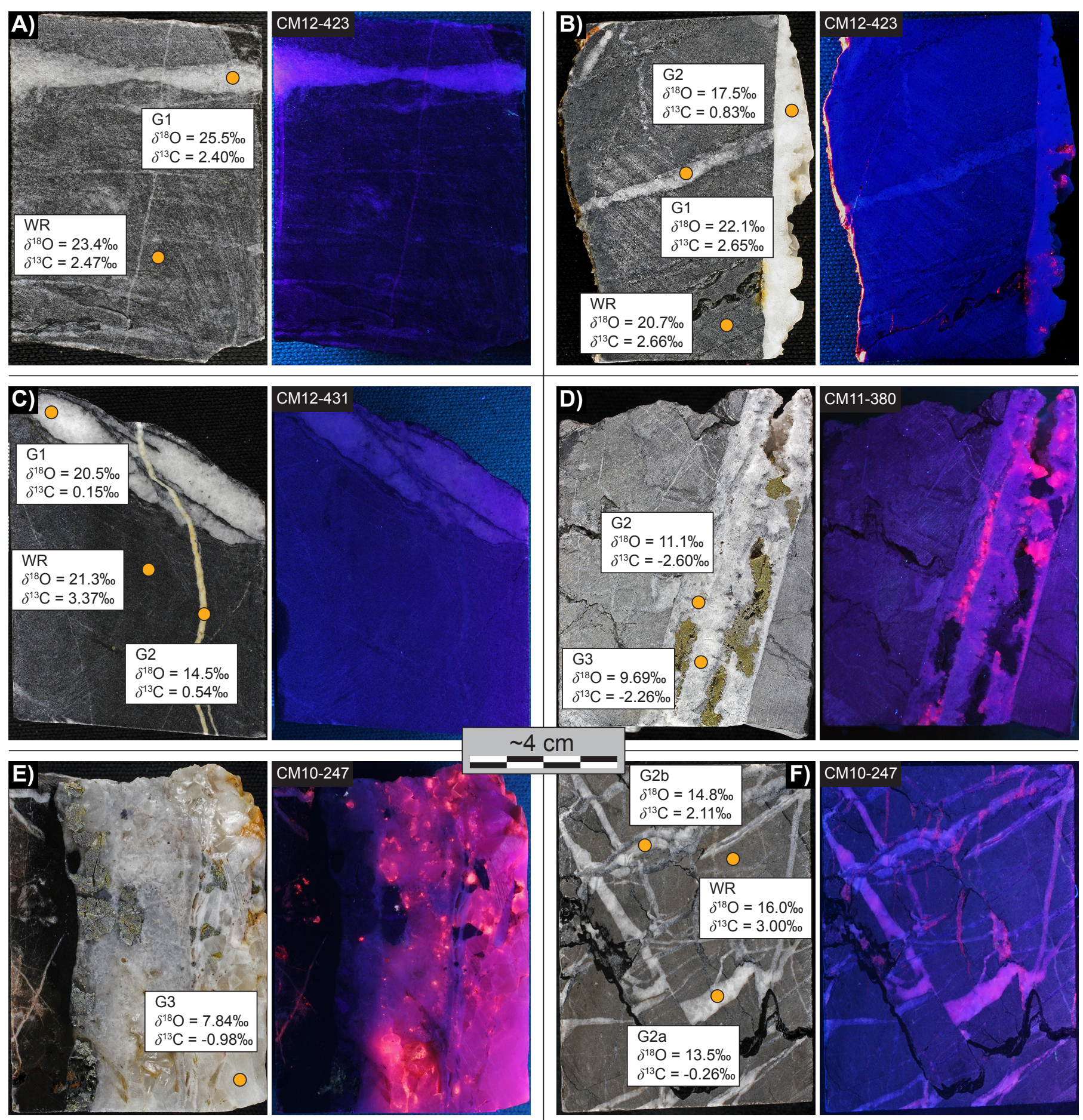

$\sim 4 \mathrm{~cm}$
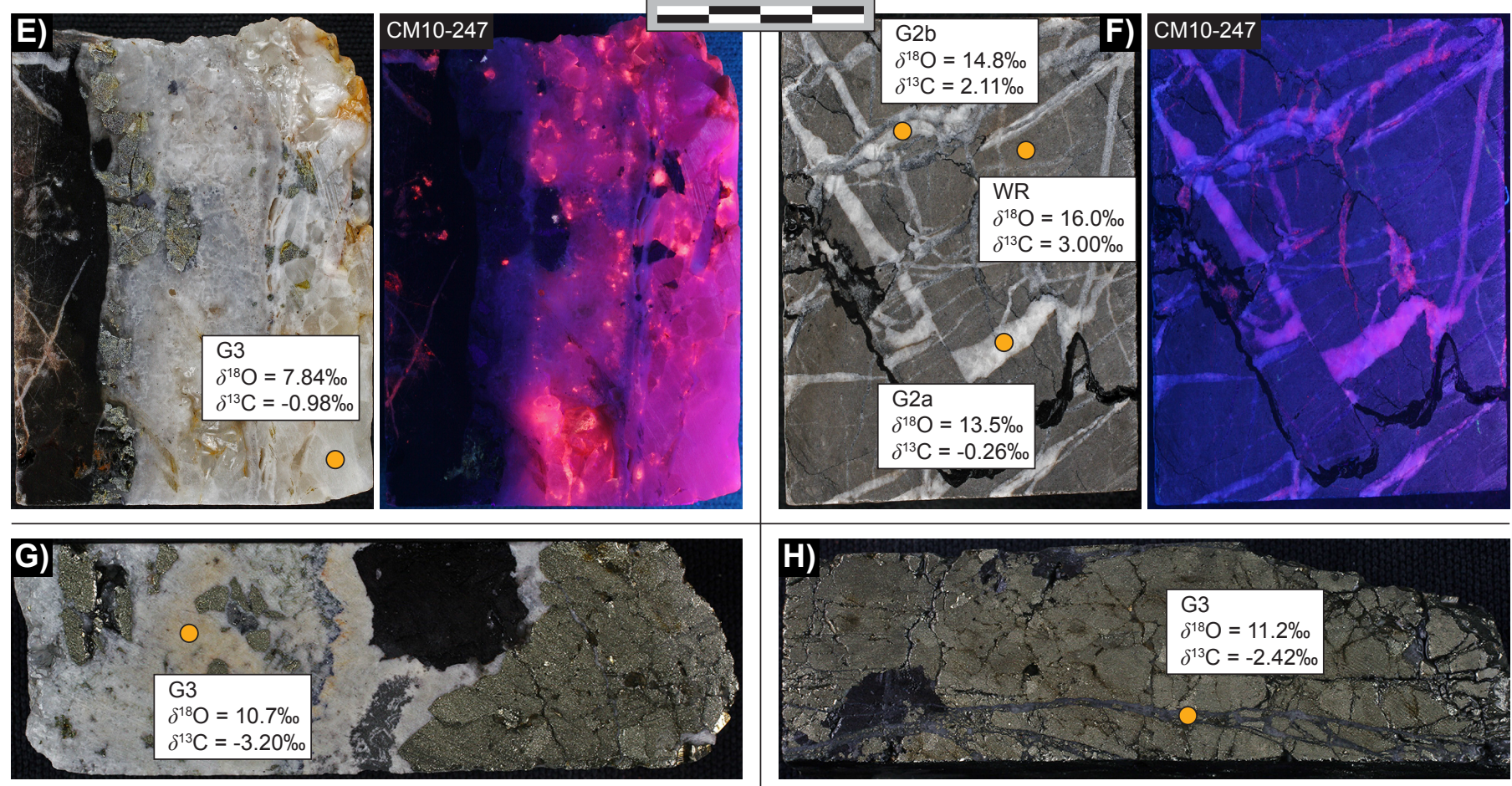

CM12-431

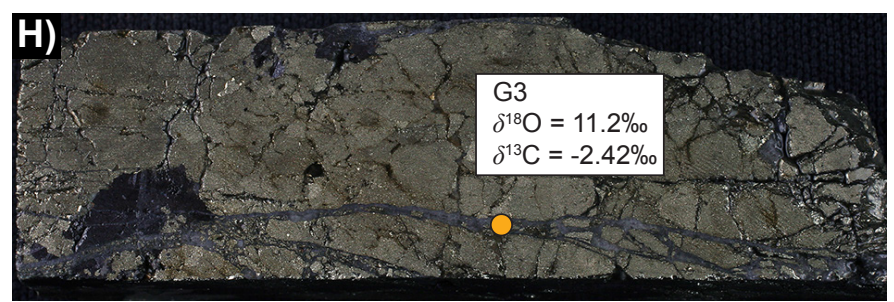

CM12-431 
Figure 5

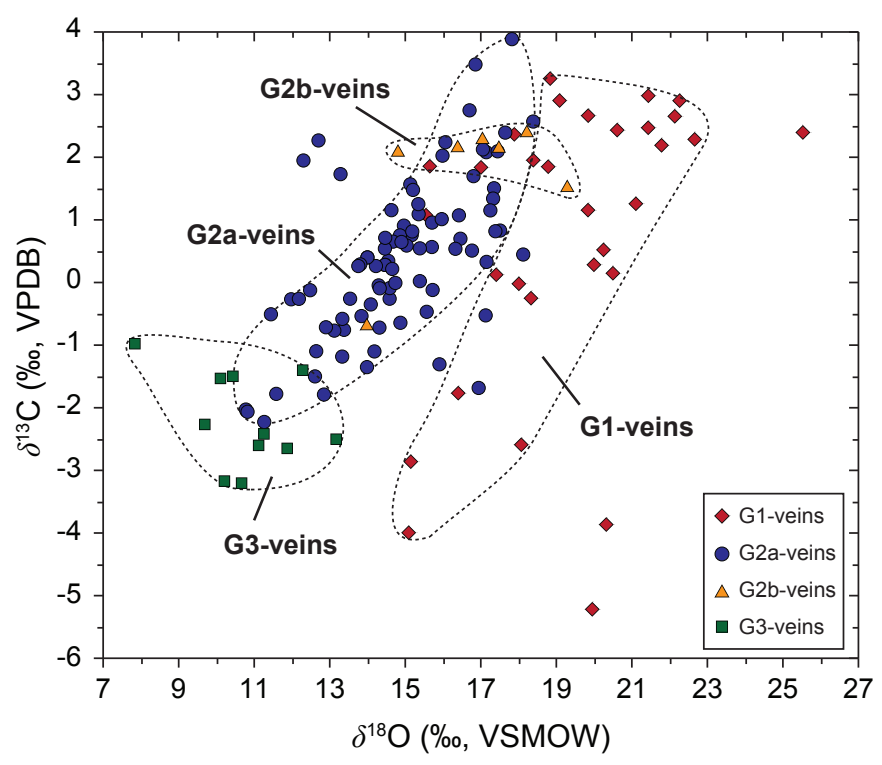


Figure 6

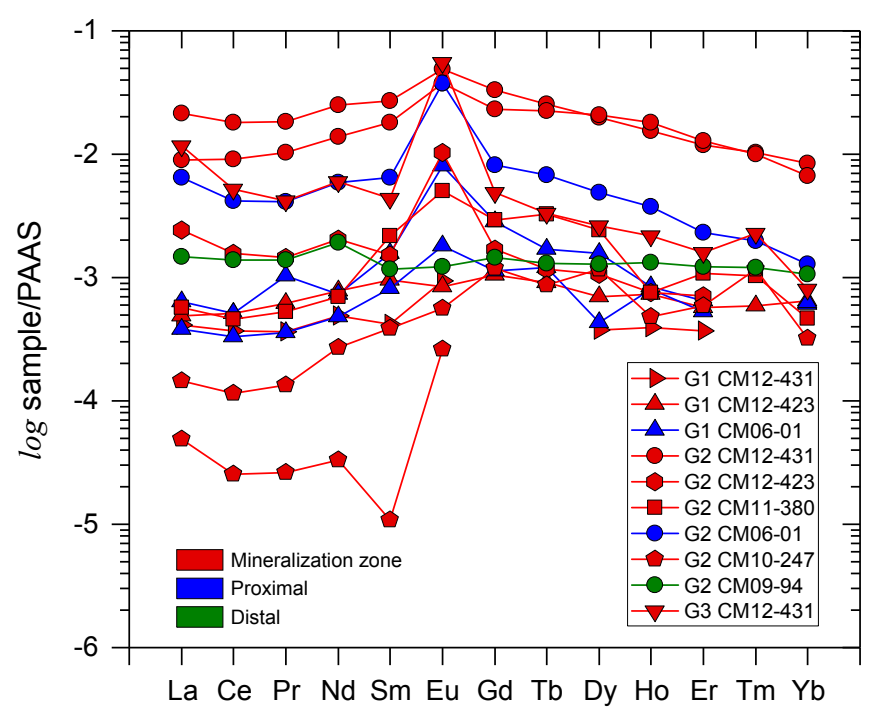


Figure 7

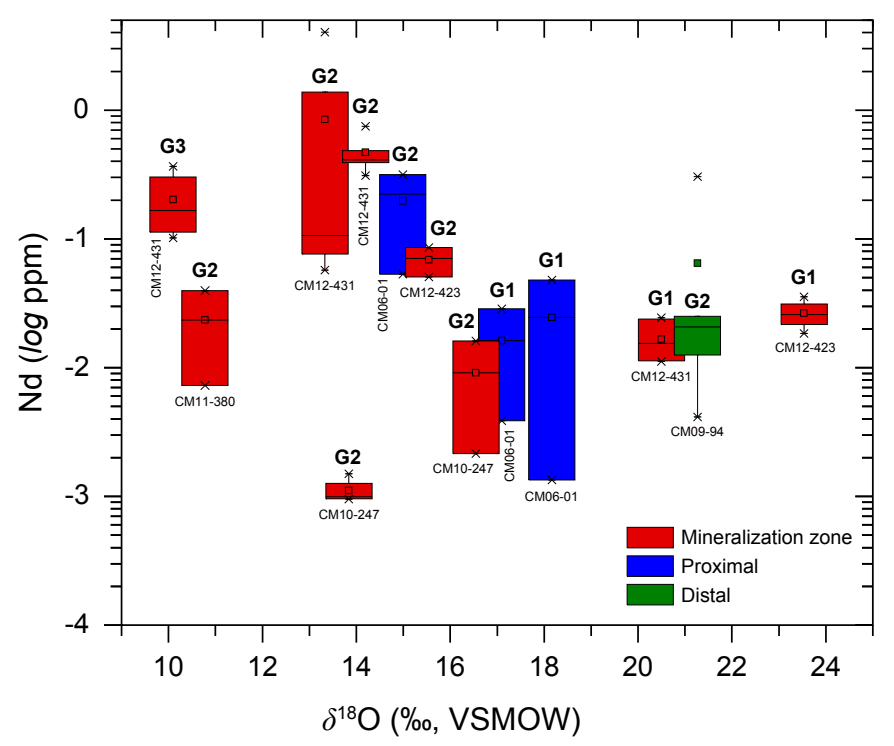


Figure 8
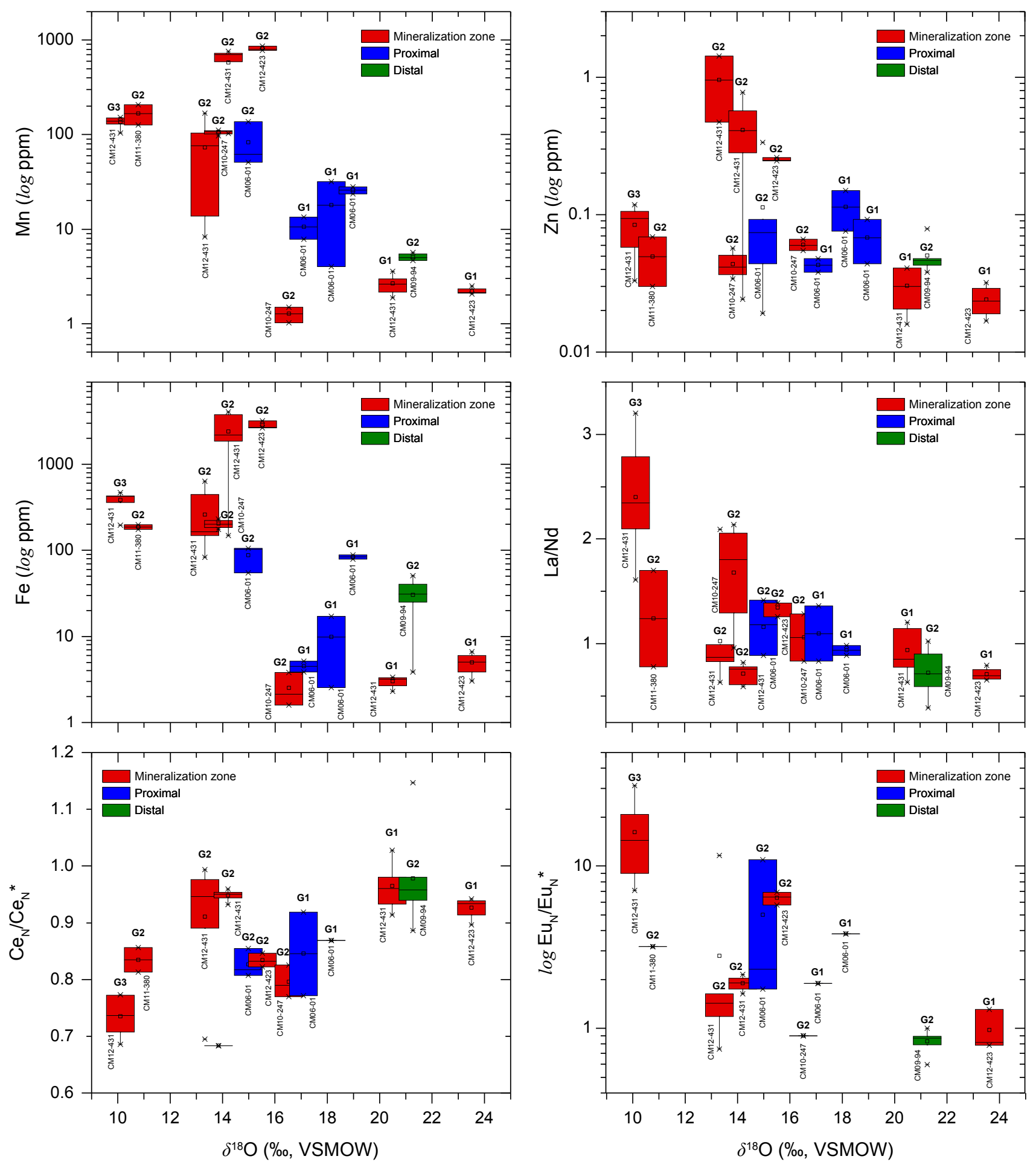
Figure 9
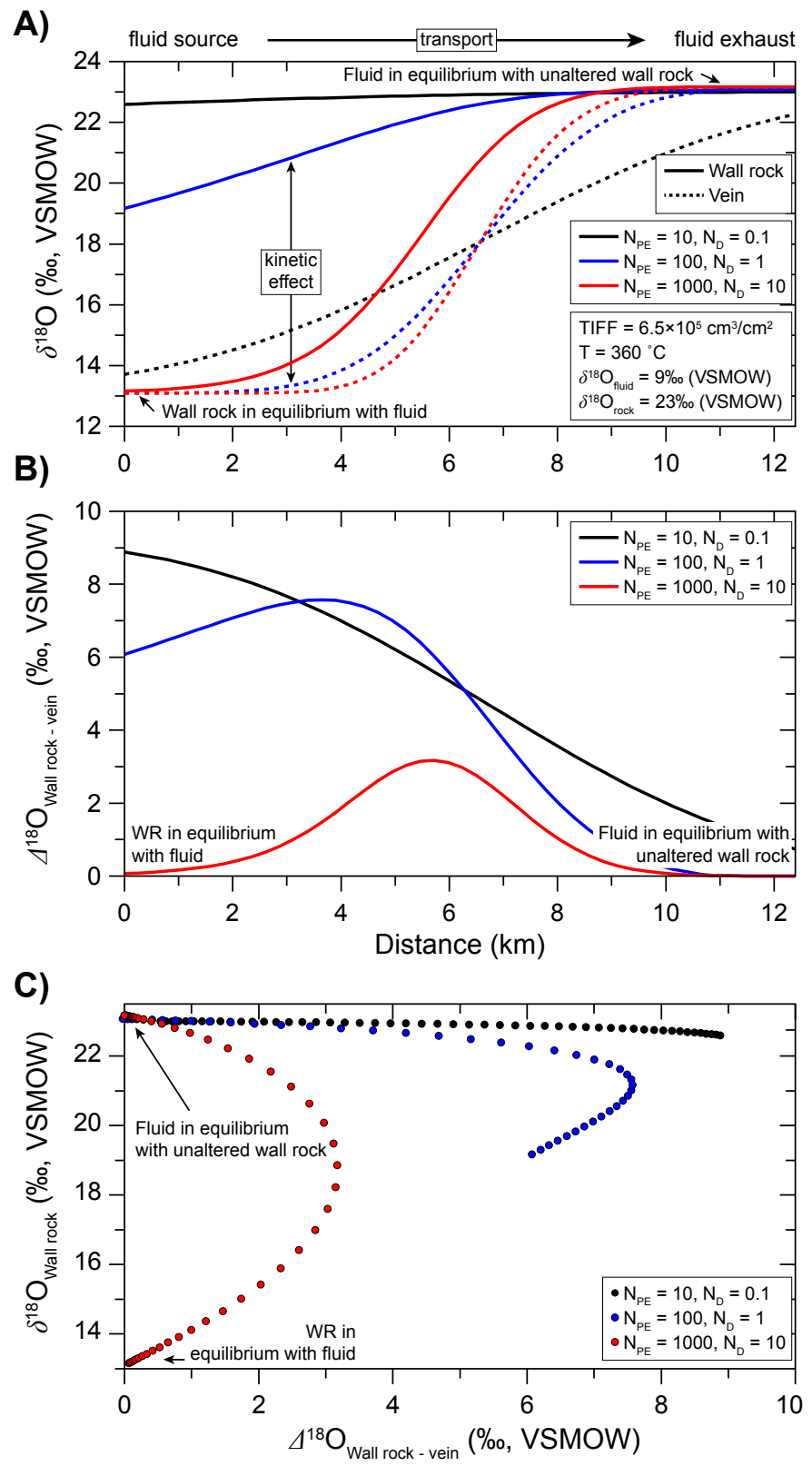
Figure 10
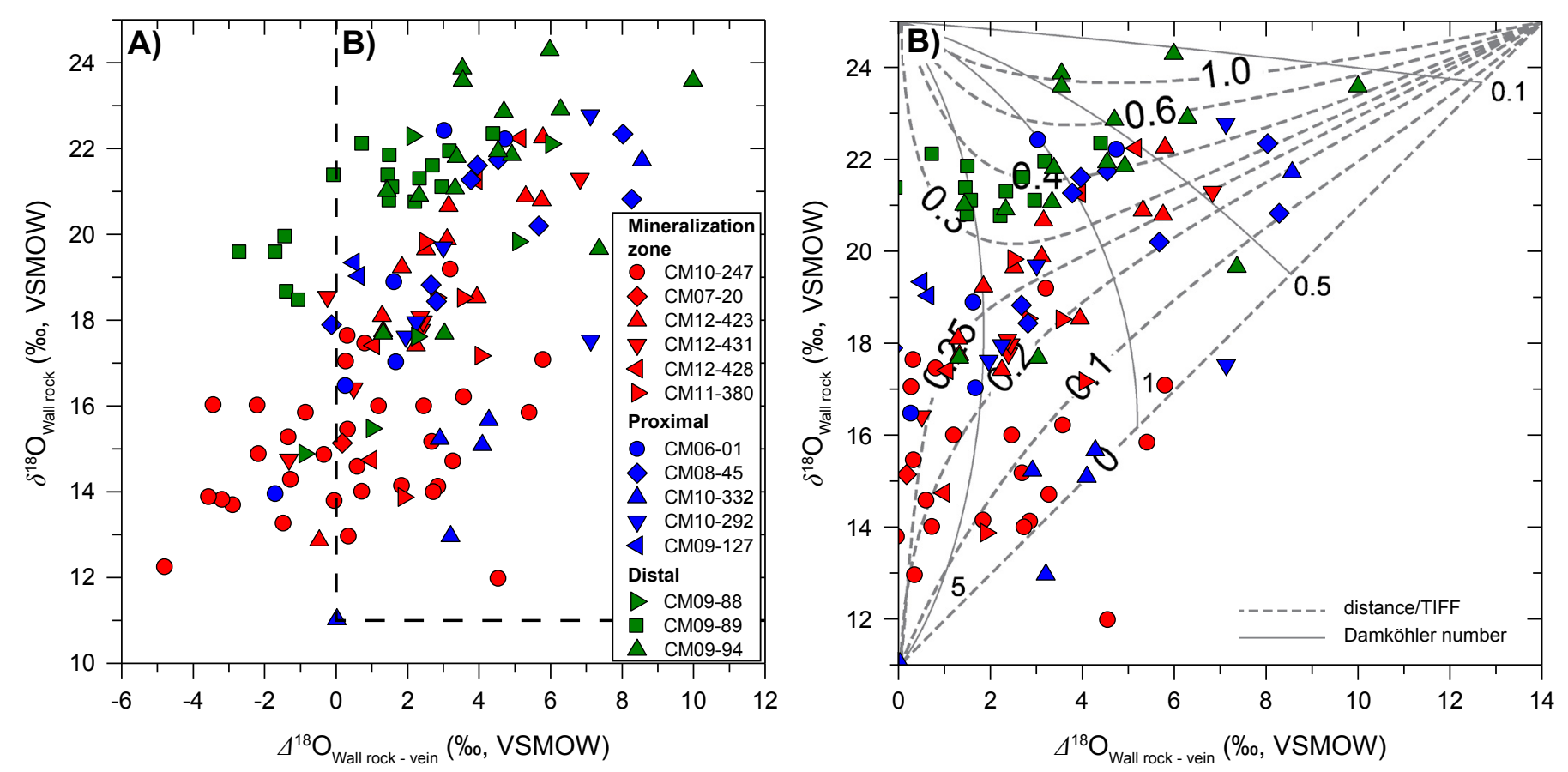
Figure 11

\section{A) Finlay wall rock}
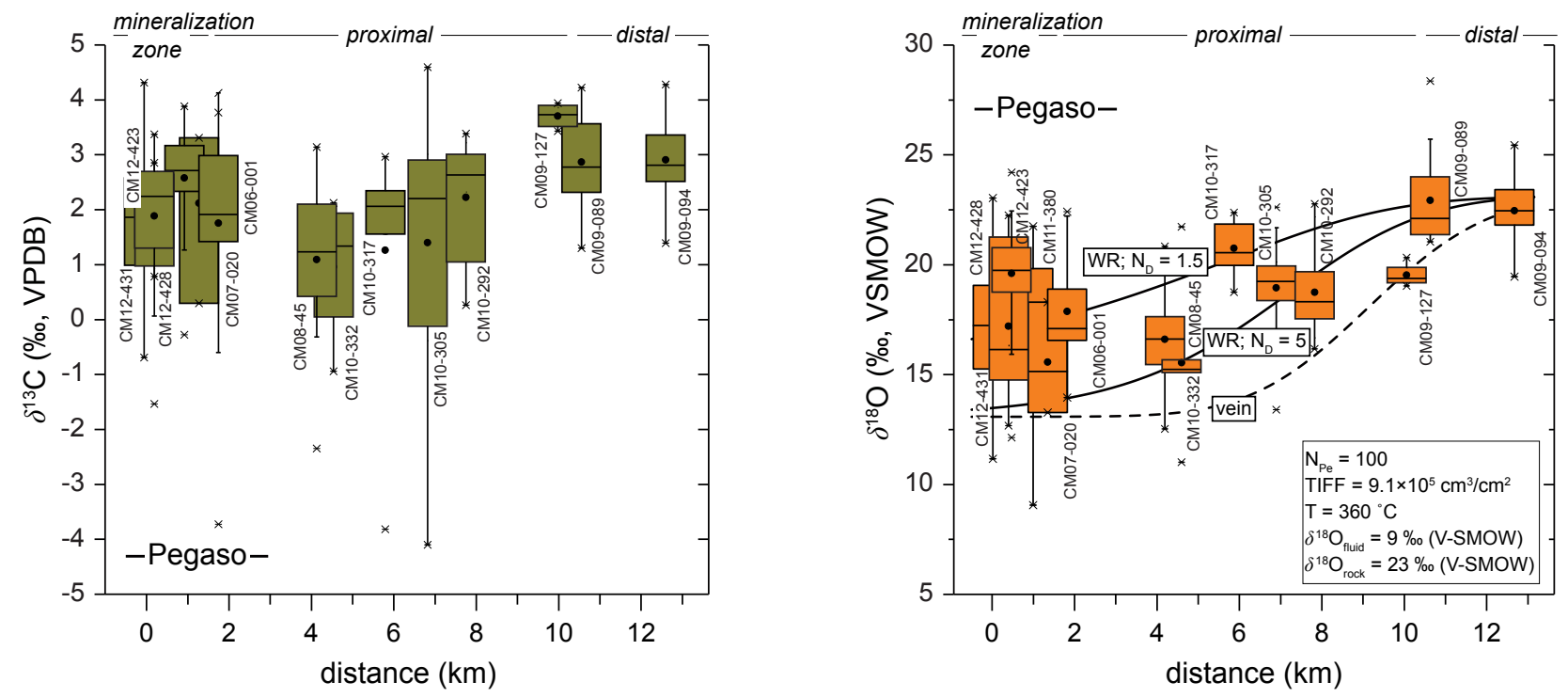

\section{B) Finlay $\mathbf{G} 2$ veins}
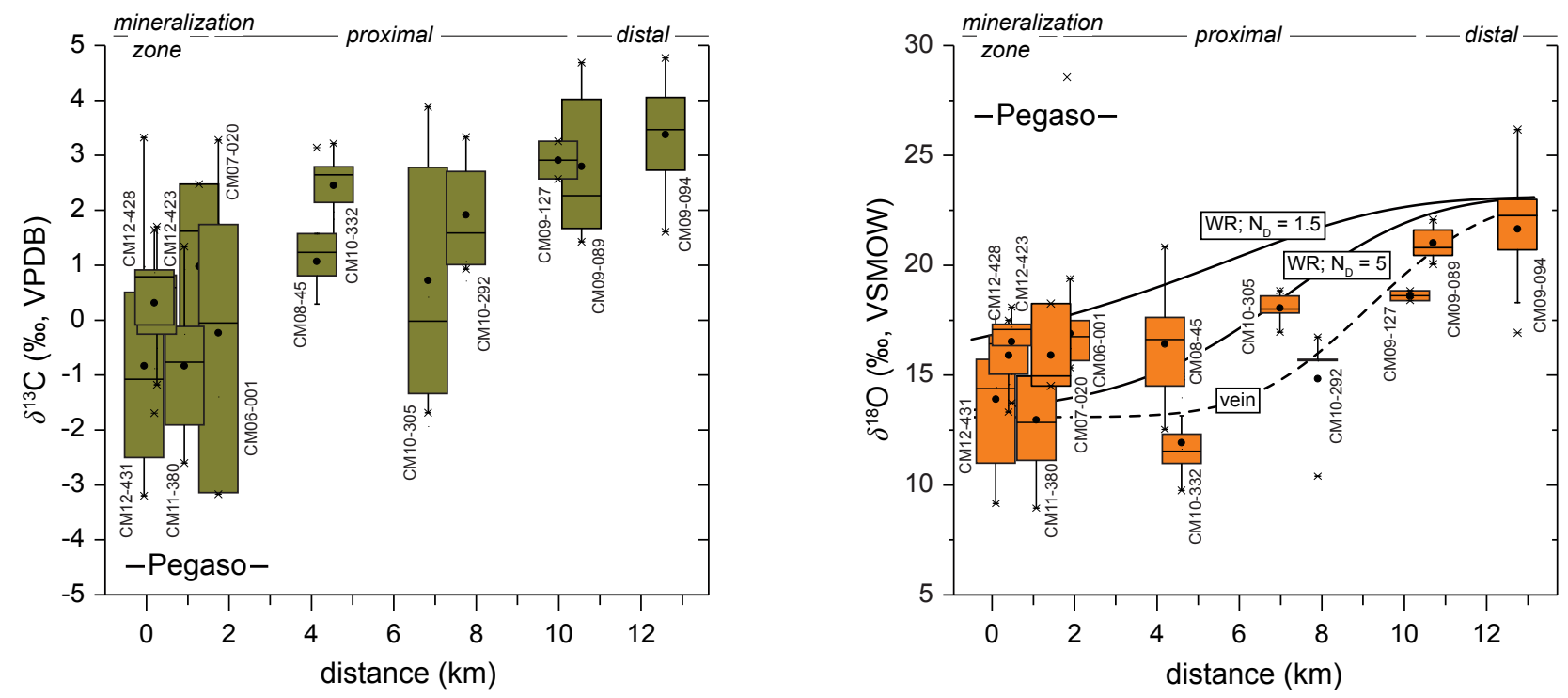
Table 1 Summary and description of limestone formations at Cinco de Mayo.

\begin{tabular}{|l|l|l|l|}
\hline Formation & Age & Description & Thickness \\
\hline Benavides & $\begin{array}{l}\text { Late } \\
\text { Albian }\end{array}$ & $\begin{array}{l}\text { Medium gray, argillaceous limestone to variably fossiliferous and calcareous shale } \\
\text { sequence. Indicative alternation of dark gray calcareous shale with light gray } \\
\text { micritic limestone on the tens of meter scale. }\end{array}$ & $\sim 300-400 \mathrm{~m}$ \\
\hline Finlay & $\begin{array}{l}\text { Middle } \\
\text { Albian }\end{array}$ & $\begin{array}{l}\text { Medium gray carbonate with variable fossil content and black chert. Carbonate } \\
\text { anges from micrite to sparite and calcarenites. The upper 20 m sometimes contain } \\
\text { by hematite stained solution cavities, coarse white calcite, and chalcedony-quartz } \\
\text { deposits. This zone as well as the upper and lower stratigraphic contacts are the } \\
\text { main loci for mineralization. }\end{array}$ & $\sim 100-200 \mathrm{~m}$ \\
\hline Lagrima & $\begin{array}{l}\text { Middle } \\
\text { Albian }\end{array}$ & $\begin{array}{l}\text { Black calcareous shale to dark gray, variably fossiliferous argillaceous limestone. } \\
\text { The black shale dominates in drill core and frequently contains thin beds of } \\
\text { limestone. }\end{array}$ & $\sim 30-100 \mathrm{~m}$ \\
\hline Benigno & $\begin{array}{l}\text { Early } \\
\text { Albian }\end{array}$ & $\begin{array}{l}\text { Medium gray carbonate with variable fossil content, variable black chert and } \\
\text { minor shale partings. Within the district, the Benigno fomation is capped by a very } \\
\text { distinctive, strongly bioturbated carbonate mud transition zone from the Lagrima } \\
\text { Formation. The carbonate ranges from micrite to sparite displaying a rich biotic } \\
\text { carbonate mud supported reef environment. }\end{array}$ & $\sim 200-300 \mathrm{~m}$ \\
\hline Cuchillo & Aptian & $\begin{array}{l}\text { Alternating 1 to 20 meter thick limestone beds interbedded with calcareous black } \\
\text { shale of equal thinkesses. }\end{array}$ & $>500 \mathrm{~m}$ \\
\hline
\end{tabular}


Table 2 Average carbon and oxygen isotope composition of limestone wall rock (WR) and vein samples outside of the Finlay Formation. The standard deviation (1 $\sigma$ ) reflects the spread of the overall data population.

\begin{tabular}{|c|c|c|c|c|c|c|c|c|c|c|c|c|c|c|c|c|c|c|c|c|}
\hline & \multicolumn{5}{|c|}{ Benavides } & \multicolumn{5}{|c|}{ Lagrima } & \multicolumn{5}{|c|}{ Benigno } & \multicolumn{5}{|c|}{ Cuchillo } \\
\hline & $\begin{array}{c}\delta^{13} \mathrm{C}(\%, \\
\mathrm{VPDB})\end{array}$ & $\begin{array}{l}\text { s.d. } \\
\delta^{13} \mathrm{C}\end{array}$ & $\begin{array}{l}\delta^{18} \mathrm{O}(\%, \\
\text { VSMOW) }\end{array}$ & $\begin{array}{l}\text { s.d. } \\
\delta^{18} \mathrm{O}\end{array}$ & $\mathrm{n}$ & $\begin{array}{l}\delta^{13} \mathrm{C}(\%, \\
\text { VPDB) }\end{array}$ & $\begin{array}{l}\text { s.d. } \\
\delta^{13} \mathrm{C}\end{array}$ & $\begin{array}{l}\delta^{18} \mathrm{O}(\%, \\
\text { VSMOW) }\end{array}$ & $\begin{array}{l}\text { s.d. } \\
\delta^{18} \mathrm{O}\end{array}$ & $\mathrm{n}$ & $\begin{array}{l}\delta^{13} \mathrm{C}(\%, \\
\text { VPDB) }\end{array}$ & $\begin{array}{l}\text { s.d. } \\
\delta^{13} \mathrm{C}\end{array}$ & $\begin{array}{l}\delta^{18} \mathrm{O}(\%, \\
\text { VSMOW) }\end{array}$ & $\begin{array}{l}\text { s.d. } \\
\delta^{18} \mathrm{O}\end{array}$ & $\mathrm{n}$ & $\begin{array}{c}\delta^{13} \mathrm{C}(\%, \\
\text { VPDB) }\end{array}$ & $\begin{array}{l}\text { s.d. } \\
\delta^{13} \mathrm{C}\end{array}$ & $\begin{array}{l}\delta^{18} \mathrm{O}(\%, \\
\text { VSMOW) }\end{array}$ & $\begin{array}{l}\text { s.d. } \\
\delta^{18} \mathrm{O}\end{array}$ & $\mathrm{n}$ \\
\hline CM09-94 WR & 3.12 & 0.62 & 22.26 & 1.77 & 31 & 3.19 & 0.87 & 22.34 & 2.44 & 14 & & & & & & & & & & \\
\hline CM09-94 veins & 2.66 & 1.11 & 21.10 & 2.25 & 19 & 3.01 & 0.85 & 18.01 & 2.78 & 15 & & & & & & & & & & \\
\hline CM09-88 WR & & & & & & & & & & & 2.81 & 1.66 & 22.01 & 1.31 & 19 & 2.66 & 1.14 & 18.19 & 2.35 & 12 \\
\hline CM09-88 veins & & & & & & & & & & & 0.16 & 4.29 & 19.37 & 2.83 & 12 & 1.28 & 0.82 & 16.66 & 2.42 & 9 \\
\hline CM09-89 WR & & & & & & 2.51 & 0.42 & 20.49 & 1.22 & 9 & 3.65 & 0.51 & 20.99 & 1.53 & 36 & 3.42 & 0.56 & 20.82 & 1.60 & 32 \\
\hline CM09-89 veins & & & & & & 1.73 & 0.36 & 18.74 & 0.96 & 3 & 3.23 & 1.48 & 20.58 & 1.46 & 22 & 3.26 & 0.81 & 20.48 & 1.44 & 23 \\
\hline CM09-127 WR & 2.14 & 0.72 & 19.01 & 1.61 & 5 & 2.74 & 0.47 & 15.52 & 1.55 & 3 & 2.43 & 0.28 & 20.34 & 0.40 & 4 & & & & & \\
\hline CM09-127 veins & 1.30 & 1.80 & 17.23 & 2.14 & 4 & 1.85 & 0.61 & 16.83 & 2.06 & 3 & & & & & & & & & & \\
\hline CM10-292 WR & & & & & & 1.61 & 2.25 & 21.65 & 6.17 & 2 & 2.48 & 0.57 & 22.49 & 3.19 & 3 & & & & & \\
\hline CM10-292 veins & & & & & & 2.05 & 0.98 & 15.49 & 11.86 & 2 & 1.40 & 0.90 & 20.26 & 0.56 & 2 & & & & & \\
\hline CM10-305 WR & & & & & & 3.89 & & 17.82 & & 1 & & & & & & & & & & \\
\hline CM10-305 veins & & & & & & 3.55 & & 9.72 & & 1 & & & & & & & & & & \\
\hline CM11-380 WR & & & & & & 3.05 & 0.44 & 17.86 & 2.91 & 7 & & & & & & & & & & \\
\hline CM11-380 veins & & & & & & 1.48 & 1.45 & 17.07 & 3.22 & 8 & & & & & & & & & & \\
\hline CM12-423 WR & & & & & & 2.01 & 1.24 & 18.54 & 1.79 & 16 & 2.30 & 0.54 & 21.77 & 1.60 & 18 & & & & & \\
\hline CM12-423 veins & & & & & & 0.73 & 0.59 & 16.04 & 2.06 & 12 & 1.88 & 0.80 & 21.29 & 5.06 & 3 & & & & & \\
\hline CM12-431 WR & 1.77 & 0.96 & 14.65 & 1.63 & 12 & & & & & & 2.69 & 1.06 & 20.94 & 2.30 & 30 & & & & & \\
\hline CM12-431 veins & -0.37 & 1.19 & 14.32 & 0.70 & 14 & & & & & & 1.83 & 1.19 & 13.22 & 3.02 & 3 & & & & & \\
\hline CM10-247 WR & & & & & & 1.83 & 1.07 & 14.44 & 0.98 & 7 & 2.60 & 1.05 & 15.99 & 2.02 & 35 & 2.96 & 0.55 & 14.42 & 1.04 & 7 \\
\hline CM10-247 veins & & & & & & 0.17 & 2.00 & 17.32 & 0.98 & 5 & 1.65 & 1.20 & 15.17 & 5.27 & 27 & 1.96 & 0.81 & 15.87 & 2.44 & 13 \\
\hline
\end{tabular}


Table 3 Average carbon and oxygen isotope composition of Finlay limestone wall rock and G2 vein samples. The standard deviation $(1 \sigma)$ reflects the spread of the overall data population.

\begin{tabular}{|c|c|c|c|c|c|c|c|c|c|c|c|}
\hline \multirow[b]{2}{*}{ Core ID } & \multicolumn{5}{|c|}{ Wall rock } & \multicolumn{5}{|c|}{ G2 veins } & \multirow[b]{2}{*}{$\begin{array}{l}\text { Distance from } \\
\text { CM12-431 (km) }\end{array}$} \\
\hline & $\begin{array}{c}\delta^{13} \mathrm{C}(\%, \\
\mathrm{VPDB})\end{array}$ & s.d. $\delta^{13} \mathrm{C}$ & $\begin{array}{l}\delta^{18} \mathrm{O}(\% \text {, } \\
\text { VSMOW) }\end{array}$ & $\begin{array}{l}\text { s.d. } \\
\delta^{18} \mathrm{O}\end{array}$ & $\mathrm{n}$ & $\begin{array}{c}\delta^{13} \mathrm{C}(\% \text {, } \\
\text { VPDB) }\end{array}$ & s.d. $\delta{ }^{13} \mathrm{C}$ & $\begin{array}{l}\delta^{18} \mathrm{O}(\% \text {, } \\
\text { VSMOW) }\end{array}$ & $\begin{array}{l}\text { s.d. } \\
\delta^{18} \mathrm{O}\end{array}$ & $\mathrm{n}$ & \\
\hline \multicolumn{12}{|l|}{ Distal cores } \\
\hline CM09-94 & 2.89 & 0.63 & 22.45 & 1.29 & 27 & 3.36 & 0.96 & 21.66 & 2.26 & 17 & 12.7 \\
\hline CM09-88 & \multicolumn{10}{|c|}{ Finlay Formation not present in CM09-88 } & 11.1 \\
\hline CM09-89 & 2.85 & 0.80 & 22.94 & 2.26 & 11 & 2.78 & 1.34 & 21.00 & 0.71 & 7 & 10.6 \\
\hline \multicolumn{12}{|l|}{ Proximal cores } \\
\hline CM09-127 & 3.71 & 0.23 & 19.52 & 0.55 & 4 & 2.91 & 0.48 & 18.61 & 0.32 & 2 & 10.1 \\
\hline CM10-292 & 2.23 & 1.13 & 18.73 & 2.00 & 10 & 1.91 & 1.06 & 14.82 & 2.51 & 5 & 7.8 \\
\hline CM10-305 & 1.39 & 2.22 & 18.94 & 2.11 & 29 & 0.73 & 2.49 & 18.04 & 0.74 & 5 & 6.9 \\
\hline CM10-317 & 1.25 & 2.09 & 20.76 & 1.25 & 13 & \multicolumn{5}{|c|}{ No G2 veins present in CM10-317 } & 5.9 \\
\hline CM10-332 & 0.96 & 1.17 & 15.51 & 2.92 & 9 & 2.45 & 0.55 & 11.90 & 1.48 & 9 & 4.5 \\
\hline CM08-45 & 1.08 & 1.33 & 16.61 & 2.06 & 15 & 1.05 & 1.57 & 16.43 & 2.44 & 9 & 4.1 \\
\hline CM06-01 & 1.74 & 2.04 & 17.88 & 2.46 & 13 & -0.23 & 2.72 & 16.89 & 1.49 & 6 & 1.8 \\
\hline \multicolumn{12}{|c|}{ Mineralization zone cores } \\
\hline \multicolumn{12}{|c|}{ Pegaso Zone mineralization } \\
\hline CM07-20 & 2.10 & 1.60 & 15.57 & 2.54 & 3 & 0.96 & 1.89 & 15.91 & 2.04 & 3 & 1.4 \\
\hline CM11-380 & 2.56 & 0.95 & 17.44 & 3.21 & 27 & -0.83 & 1.36 & 12.94 & 2.69 & 13 & 1.0 \\
\hline CM12-423 & 1.87 & 1.16 & 19.62 & 2.21 & 49 & 0.37 & 0.78 & 15.89 & 1.30 & 13 & 0.3 \\
\hline CM12-428 & 1.88 & 0.87 & 17.20 & 3.85 & 6 & 0.31 & 1.28 & 16.51 & 1.67 & 5 & 0.3 \\
\hline CM12-431 & 1.78 & 1.17 & 17.18 & 2.69 & 43 & -0.84 & 1.86 & 13.90 & 3.22 & 21 & 0.0 \\
\hline \multicolumn{12}{|c|}{ Pozo Seco Zone mineralization } \\
\hline CM10-247 & 2.47 & 0.74 & 14.48 & 1.35 & 25 & -0.53 & 1.12 & 13.19 & 1.45 & 8 & 6.0 \\
\hline
\end{tabular}


Table 4 Average trace-element concentrations in Finlay calcite veins from the mineralization zone, proximal and distal holes together with their stable isotope composition.

\begin{tabular}{|c|c|c|c|c|c|c|c|c|c|c|c|c|c|c|}
\hline Hole ID & \multicolumn{2}{|c|}{ CM09-94 } & \multicolumn{2}{|c|}{ CM11-380 } & \multicolumn{2}{|c|}{ CM06-01 } & \multicolumn{2}{|c|}{ CM06-01 } & \multicolumn{2}{|c|}{ CM06-01 } & \multicolumn{2}{|c|}{ CM06-01 } & \multicolumn{2}{|c|}{ JM12-423 } \\
\hline Vein type & \multicolumn{2}{|c|}{ G2 } & \multicolumn{2}{|c|}{ G2 } & \multicolumn{2}{|c|}{ G1 } & \multicolumn{2}{|c|}{ G1 } & \multicolumn{2}{|c|}{ G2 } & \multicolumn{2}{|c|}{ G2 } & \multicolumn{2}{|c|}{ G1 } \\
\hline$\delta^{13} \mathrm{C}$ (\%) & \multicolumn{2}{|c|}{$3.0 \pm 0.5$} & \multicolumn{2}{|c|}{$-2.0 \pm 0.5$} & \multicolumn{2}{|c|}{$2.6 \pm 0.8$} & \multicolumn{2}{|c|}{$2.1 \pm 0.8$} & \multicolumn{2}{|c|}{$1.4 \pm 0.8$} & \multicolumn{2}{|c|}{$-1.4 \pm 0.8$} & \multicolumn{2}{|c|}{$1.64 \pm 0.8$} \\
\hline$\delta^{18} \mathrm{O}(\%)$ & \multicolumn{2}{|c|}{$21.3 \pm 0.8$} & \multicolumn{2}{|c|}{$10.8 \pm 0.7$} & \multicolumn{2}{|c|}{$17.1 \pm 0.2$} & 18.2 & & 19.0 & & 15.0 & & 23.5 & \\
\hline $\bar{n}$ & t & & & & & & & & & & 3 & & & \\
\hline & avg ppm & s.d. & avg ppm & s.d. & avg ppm & s.d. & avg ppm & s.d. & avg ppm & s.d. & avg ppm & s.d. & avg ppm & s.d. \\
\hline $\mathrm{Mg}$ & 33.3 & 9.15 & 78.6 & 45.4 & 31.3 & 1.28 & 37.0 & 0.877 & 32.0 & 5.30 & 28.0 & 10.5 & 163 & 12.4 \\
\hline Si & 14.5 & 2.38 & 13.2 & 2.40 & 15.5 & 0.495 & 12.8 & 1.13 & 12.3 & 0.283 & 28.5 & 22.1 & 9.70 & 1.28 \\
\hline$P$ & 0.220 & b.d.l. & b.d.l. & b.d.l. & b.d.l. & b.d.l. & b.d.l. & b.d.l. & 0.670 & 0.255 & 0.362 & b.d.l. & b.d.l. & b.d.l. \\
\hline S & 1.96 & 0.204 & 4.00 & 0.297 & 2.73 & 0.417 & 2.57 & 0.148 & 27.1 & 2.41 & 8.32 & 5.49 & 3.33 & 0.430 \\
\hline Mn & 5.06 & 0.424 & 167 & 57.9 & 10.6 & 3.96 & 17.9 & 19.7 & 25.8 & 3.16 & 82.9 & 46.6 & 2.21 & 0.196 \\
\hline $\mathrm{Fe}$ & 30.4 & 15.8 & 187 & 16.0 & 4.52 & 0.905 & 9.85 & 10.4 & 83.8 & 7.00 & 87.8 & 28.3 & 4.94 & 1.50 \\
\hline $\mathrm{Cu}$ & 0.008 & 0.009 & 0.002 & 0.000 & 0.004 & 0.001 & 0.003 & b.d.l. & 0.018 & b.d.l. & 0.005 & 0.003 & 0.005 & 0.003 \\
\hline $\mathrm{Zn}$ & 0.050 & 0.015 & 0.050 & 0.028 & 0.043 & 0.007 & 0.113 & 0.052 & 0.068 & 0.034 & 0.143 & 0.169 & 0.024 & 0.007 \\
\hline As & 0.017 & 0.012 & 0.012 & 0.001 & 0.015 & 0.006 & 0.011 & 0.002 & 0.011 & 0.004 & 0.011 & 0.001 & 0.009 & 0.002 \\
\hline Sr & 4.04 & 0.608 & 13.3 & 5.73 & 9.23 & 5.18 & 6.73 & 0.278 & 9.06 & 5.08 & 9.09 & 1.95 & 12.9 & 0.219 \\
\hline Y & 0.039 & 0.005 & 0.037 & 0.047 & 0.013 & 0.013 & 0.016 & 0.021 & 0.010 & 0.002 & 0.129 & 0.054 & 0.020 & 0.007 \\
\hline $\mathrm{Ba}$ & 0.016 & 0.004 & 0.022 & 0.008 & 0.028 & 0.010 & 0.022 & 0.012 & 0.013 & 0.014 & 0.268 & 0.418 & 0.010 & 0.002 \\
\hline $\mathrm{La}$ & 0.056 & 0.108 & 0.022 & 0.013 & 0.015 & 0.013 & 0.024 & 0.033 & b.d.l. & b.d.l. & 0.246 & 0.175 & 0.019 & 0.005 \\
\hline $\mathrm{Ce}$ & 0.110 & 0.208 & 0.036 & 0.031 & 0.026 & 0.027 & 0.041 & 0.053 & b.d.l. & b.d.l. & 0.334 & 0.225 & 0.041 & 0.010 \\
\hline $\operatorname{Pr}$ & 0.012 & 0.022 & 0.005 & 0.005 & 0.003 & 0.003 & 0.009 & b.d.l. & b.d.l. & b.d.l. & 0.037 & 0.024 & 0.005 & 0.002 \\
\hline $\mathrm{Nd}$ & 0.065 & 0.118 & 0.024 & 0.023 & 0.016 & 0.018 & 0.025 & 0.033 & b.d.l. & b.d.l. & 0.198 & 0.134 & 0.027 & 0.007 \\
\hline Sm & 0.006 & 0.007 & 0.012 & b.d.l. & 0.005 & b.d.l. & 0.009 & b.d.l. & b.d.l. & b.d.l. & 0.036 & 0.023 & 0.005 & 0.002 \\
\hline $\mathrm{Eu}$ & 0.001 & 0.001 & 0.005 & 0.005 & 0.002 & 0.000 & 0.009 & b.d.l. & b.d.l. & b.d.l. & 0.040 & 0.047 & 0.001 & 0.000 \\
\hline Gd & 0.007 & 0.004 & 0.014 & b.d.l. & 0.005 & b.d.l. & 0.013 & b.d.l. & b.d.l. & b.d.l. & 0.038 & 0.024 & 0.005 & 0.002 \\
\hline $\mathrm{Tb}$ & 0.001 & 0.000 & 0.003 & b.d.l. & 0.001 & b.d.l. & 0.001 & b.d.l. & b.d.l. & b.d.l. & 0.005 & 0.003 & 0.001 & 0.000 \\
\hline Dy & 0.006 & 0.001 & 0.011 & b.d.l. & 0.002 & 0.002 & 0.007 & b.d.l. & b.d.l. & b.d.l. & 0.023 & 0.012 & 0.003 & 0.001 \\
\hline Но & 0.001 & 0.000 & 0.001 & 0.001 & 0.001 & b.d.l. & 0.001 & b.d.l. & b.d.l. & b.d.l. & 0.004 & 0.002 & 0.001 & 0.000 \\
\hline $\mathrm{Er}$ & 0.003 & 0.001 & 0.003 & b.d.l. & 0.002 & b.d.l. & 0.002 & b.d.l. & b.d.l. & b.d.l. & 0.007 & 0.003 & 0.002 & 0.001 \\
\hline $\mathrm{Tm}$ & 0.000 & 0.000 & 0.000 & b.d.l. & b.d.l. & b.d.l. & b.d.l. & b.d.l. & b.d.l. & b.d.l. & 0.001 & 0.000 & 0.000 & 0.000 \\
\hline $\mathrm{Yb}$ & 0.003 & 0.000 & 0.001 & b.d.l. & 0.002 & b.d.l. & 0.002 & b.d.l. & 0.000 & b.d.l. & 0.004 & 0.002 & 0.002 & b.d.l. \\
\hline $\mathrm{Hf}$ & 0.001 & 0.001 & b.d.l. & b.d.l. & b.d.l. & b.d.l. & b.d.l. & b.d.l. & b.d.l. & b.d.l. & 0.001 & b.d.l. & b.d.l. & b.d.l. \\
\hline $\mathrm{Tl}$ & b.d.l. & b.d.l. & b.d.l. & b.d.l. & b.d.l. & b.d.l. & b.d.l. & b.d.l. & b.d.l. & b.d.l. & b.d.l. & b.d.l. & b.d.l. & b.d.l. \\
\hline $\mathrm{Pb}$ & 0.002 & 0.001 & 0.016 & 0.007 & 0.005 & 0.000 & 0.008 & 0.006 & 0.003 & 0.002 & 0.048 & 0.069 & 0.025 & 0.024 \\
\hline Th & 0.000 & 0.001 & b.d.l. & b.d.l. & b.d.l. & b.d.l. & b.d.l. & b.d.l. & b.d.l. & b.d.l. & 0.001 & 0.002 & b.d.l. & b.d.l. \\
\hline $\mathrm{U}$ & 0.002 & 0.003 & 0.002 & 0.001 & 0.000 & b.d.l. & 0.000 & 0.000 & 0.001 & b.d.l. & 0.003 & 0.003 & 0.002 & 0.003 \\
\hline
\end{tabular}


Table 4 continued.

\begin{tabular}{|c|c|c|c|c|c|c|c|c|c|c|c|c|c|c|}
\hline Hole ID & \multicolumn{2}{|c|}{ JM12-423 } & \multicolumn{2}{|c|}{ CM12-431 } & \multicolumn{2}{|c|}{ CM12-431 } & \multicolumn{2}{|c|}{ CM12-431 } & \multicolumn{2}{|c|}{ CM12-431 } & \multicolumn{2}{|c|}{ CM10-247 } & \multicolumn{2}{|c|}{ CM10-247 } \\
\hline Vein type & \multicolumn{2}{|c|}{ G2 } & \multicolumn{2}{|c|}{ G1 } & \multicolumn{2}{|c|}{ G2 } & \multicolumn{2}{|c|}{ G2 } & \multicolumn{2}{|c|}{ G3 } & \multicolumn{2}{|c|}{ G2 } & \multicolumn{2}{|c|}{ G2 } \\
\hline$\delta{ }^{13} \mathrm{C}(\%)$ & \multicolumn{2}{|c|}{$0.7 \pm 0.8$} & \multicolumn{2}{|c|}{$0.1 \pm 0.2$} & \multicolumn{2}{|c|}{$-0.6 \pm 0.2$} & \multicolumn{2}{|c|}{$0.3 \pm 0.2$} & \multicolumn{2}{|c|}{$-1.5 \pm 0.1$} & \multicolumn{2}{|c|}{$1.8 \pm 0.8$} & \multicolumn{2}{|c|}{$-0.5 \pm 0.3$} \\
\hline$\delta^{18} \mathrm{O}(\%)$ & \multicolumn{2}{|c|}{$15.5 \pm 0.1$} & \multicolumn{2}{|c|}{$20.5 \pm 0.4$} & \multicolumn{2}{|c|}{$13.3 \pm 0.4$} & 14.2 & & 10.1 & & 16.5 & & 13.8 & \\
\hline$n$ & 3 & & & & & & & & & & & & & \\
\hline & avg ppm & s.d. & avg ppm & s.d. & avg ppm & s.d. & avg ppm & s.d. & avg ppm & s.d. & avg ppm & s.d. & avg ppm & s.d. \\
\hline Mg & 2356 & 200 & 81.8 & 7.63 & 79.5 & 74.8 & 1585 & 1026 & 182 & 65.6 & 41.0 & 7.41 & 56.1 & 9.25 \\
\hline Si & 17.7 & 3.50 & 22.8 & 12.0 & 125 & 173 & 23.7 & 2.66 & 13.8 & 1.90 & 15.1 & 0.635 & 14.1 & 1.75 \\
\hline $\mathrm{P}$ & b.d.l. & b.d.l. & b.d.l. & b.d.l. & 22.7 & b.d.l. & b.d.l. & b.d.l. & b.d.l. & b.d.l. & 0.298 & 0.027 & b.d.l. & b.d.l. \\
\hline $\mathrm{S}$ & 3.68 & 0.171 & 2.34 & 0.932 & 3.85 & 3.26 & 1.51 & 0.214 & 5.84 & 1.11 & 3.87 & 1.64 & 2.13 & 0.084 \\
\hline $\mathrm{Mn}$ & 813 & 44.4 & 2.66 & 0.559 & 72.5 & 54.5 & 576 & 272 & 136 & 17.5 & 1.27 & 0.235 & 106 & 6.47 \\
\hline $\mathrm{Fe}$ & 2846 & 318 & 2.99 & 0.390 & 259 & 201 & 2394 & 1579 & 383 & 98.0 & 2.50 & 1.15 & 203 & 24.1 \\
\hline $\mathrm{Cu}$ & 0.007 & 0.001 & 0.006 & 0.002 & 0.102 & 0.134 & 0.075 & 0.124 & 0.022 & 0.036 & 0.004 & 0.001 & 0.005 & 0.002 \\
\hline Zn & 0.252 & 0.008 & 0.030 & 0.011 & b.d.l. & b.d.l. & 0.412 & 0.284 & 0.084 & 0.033 & 0.060 & 0.006 & 0.044 & 0.010 \\
\hline As & 0.021 & 0.004 & 0.014 & 0.004 & 0.043 & 0.031 & 0.008 & b.d.l. & 0.030 & 0.013 & 0.013 & 0.003 & 0.008 & 0.001 \\
\hline Sr & 9.14 & 0.320 & 11.9 & 0.623 & 10.6 & 2.18 & 8.68 & 2.16 & 12.0 & 0.584 & 9.95 & 3.38 & 7.73 & 0.230 \\
\hline $\mathrm{Y}$ & 0.036 & 0.010 & 0.006 & 0.003 & 0.529 & 0.695 & 0.556 & 0.201 & 0.078 & 0.047 & 0.019 & 0.024 & 0.000 & 0.000 \\
\hline $\mathrm{Ba}$ & 0.096 & 0.005 & 0.022 & 0.016 & 0.048 & 0.038 & 0.058 & 0.016 & 0.048 & 0.017 & 0.021 & 0.005 & 0.013 & 0.008 \\
\hline $\mathrm{La}$ & 0.093 & 0.025 & 0.016 & 0.007 & 0.818 & 1.47 & 0.340 & 0.159 & 0.445 & 0.178 & 0.006 & 0.007 & 0.002 & 0.001 \\
\hline $\mathrm{Ce}$ & 0.125 & 0.035 & 0.030 & 0.011 & 1.44 & 2.55 & 0.724 & 0.307 & 0.413 & 0.219 & 0.009 & 0.012 & 0.002 & 0.001 \\
\hline $\operatorname{Pr}$ & 0.013 & 0.004 & 0.003 & 0.001 & 0.162 & 0.283 & 0.092 & 0.035 & 0.037 & 0.021 & 0.001 & 0.002 & 0.000 & b.d.l. \\
\hline $\mathrm{Nd}$ & 0.069 & 0.018 & 0.017 & 0.006 & 0.852 & 1.49 & 0.472 & 0.170 & 0.204 & 0.112 & 0.009 & 0.010 & 0.001 & 0.000 \\
\hline Sm & 0.008 & 0.001 & 0.002 & 0.001 & 0.151 & 0.265 & 0.100 & 0.031 & 0.025 & 0.016 & 0.002 & 0.002 & 0.000 & 0.000 \\
\hline $\mathrm{Eu}$ & 0.011 & 0.002 & 0.001 & 0.000 & 0.053 & 0.091 & 0.041 & 0.010 & 0.060 & 0.013 & 0.001 & 0.000 & 0.000 & 0.000 \\
\hline Gd & 0.008 & 0.002 & b.d.l. & b.d.l. & 0.155 & 0.270 & 0.108 & 0.041 & 0.023 & 0.016 & 0.006 & b.d.l. & b.d.l. & b.d.l. \\
\hline $\mathrm{Tb}$ & 0.001 & 0.000 & b.d.l. & b.d.l. & 0.020 & 0.030 & 0.017 & 0.007 & 0.003 & 0.001 & 0.001 & b.d.l. & b.d.l. & b.d.l. \\
\hline Dy & 0.005 & 0.001 & 0.002 & 0.001 & 0.093 & 0.121 & 0.097 & 0.036 & 0.012 & 0.008 & 0.006 & b.d.l. & b.d.l. & b.d.l. \\
\hline Ho & 0.001 & 0.000 & 0.000 & 0.000 & 0.015 & 0.019 & 0.018 & 0.006 & 0.002 & 0.001 & 0.000 & 0.001 & b.d.l. & b.d.l. \\
\hline $\mathrm{Er}$ & 0.002 & 0.000 & 0.001 & b.d.l. & 0.034 & 0.042 & 0.037 & 0.011 & 0.005 & 0.003 & 0.002 & 0.001 & b.d.l. & b.d.l. \\
\hline $\mathrm{Tm}$ & b.d.l. & b.d.l. & b.d.l. & b.d.l. & 0.004 & 0.005 & 0.004 & 0.001 & 0.001 & 0.000 & 0.000 & b.d.l. & b.d.l. & b.d.l. \\
\hline $\mathrm{Yb}$ & b.d.l. & b.d.l. & b.d.l. & b.d.l. & 0.024 & 0.032 & 0.019 & 0.004 & 0.002 & 0.002 & 0.001 & b.d.l. & b.d.l. & b.d.l. \\
\hline $\mathrm{Hf}$ & b.d.l. & b.d.l. & b.d.l. & b.d.l. & 0.013 & 0.010 & b.d.l. & b.d.l. & b.d.l. & b.d.l. & 0.001 & 0.000 & 0.000 & b.d.l. \\
\hline $\mathrm{Tl}$ & b.d.l. & b.d.l. & 0.002 & 0.001 & 0.001 & 0.001 & b.d.l. & b.d.l. & b.d.l. & b.d.l. & b.d.l. & b.d.l. & b.d.l. & b.d.l. \\
\hline $\mathrm{Pb}$ & 0.017 & 0.006 & 0.010 & 0.001 & 0.044 & 0.043 & 0.025 & 0.006 & 0.023 & 0.004 & 0.003 & 0.000 & 0.016 & 0.000 \\
\hline Th & 0.000 & 0.000 & b.d.l. & b.d.l. & 0.014 & 0.014 & 0.001 & 0.000 & 0.000 & 0.000 & 0.001 & 0.001 & b.d.l. & b.d.l. \\
\hline $\mathrm{U}$ & 0.002 & 0.001 & b.d.l. & b.d.l. & 0.046 & 0.062 & 0.000 & 0.000 & 0.001 & 0.000 & 0.123 & 0.103 & b.d.l. & b.d.l. \\
\hline
\end{tabular}

b.d.l. = below the detection limit. $\delta^{13} \mathrm{C}$ relative to VPDB, $\delta^{18} \mathrm{O}$ relative to VSMOW. The standard deviation $(1 \sigma)$ reflects the spread of the overall data population. 